\title{
Acyl lipid composition variation related to culture age and nitrogen concentration in continuous culture of the microalga Phaeodactylum tricornutum
}

\author{
Diego López Alonso ${ }^{\mathrm{a}, *}$, El-Hassan Belarbi ${ }^{\mathrm{b}}$, José M. Fernández-Sevilla ${ }^{\mathrm{b}}$, \\ Juan Rodríguez-Ruiz ${ }^{\mathrm{a}}$, Emilio Molina Grima ${ }^{\mathrm{b}}$ \\ ${ }^{a}$ Departamento de Biología Aplicada, Universidad de Almería, Fac. Ciencias Exp., 04071 Almería, Spain \\ ${ }^{\mathrm{b}}$ Departamento de Ingeniería Química, Universidad de Almería, 04071 Almería, Spain
}

Received 29 November 1999; received in revised form 23 February 2000

\begin{abstract}
The influence of culture age and nitrogen concentration on the distribution of fatty acids among the different acyl lipid classes has been studied in continuous cultures of the microalga Phaeodactylum tricornutum. The culture age was tested in the range of 1.15-7 days, controlled by adjusting the dilution rate of fresh medium supplied. The effect of nitrogen concentration was tested from saturating conditions to starvation by modifying nitrate concentration in the fresh medium. Culture age had almost no influence on the fatty acid content; 16:0, 16:3 and 20:5 increased moderately wherein the level of 16:1 decreased when the culture age decreased. Culture age had no effect on the total fatty acid content that remained around $11 \%$ of dry weight. Conversely, culture age had a greater impact on lipid classes, producing changes in amounts of triacylglycerols (TAG) which ranged between $43 \%$ and $69 \%$, and galactolipids (GLs) that oscillated between $20 \%$ and $40 \%$. In general, the content of polar lipids of the biomass decreased with culture age. The other factor assayed, nitrogen content, affected the fatty acid profile. Saturated and monounsaturated fatty acids accumulated when the nitrogen concentration was decreased. The experiments regarding the effect of nitrogen concentration on lipid species were carried out with cells of an average age of 3.5 days. A decrease of the nitrogen concentration caused the GL fraction to decrease from 21 to $12 \%$. Conversely, both neutral lipids (NLs) and phospolipids (PLs) increased from about 73 to $79 \%$ and from 6 to $8 \%$, respectively. In these experiments, TAG was the lipid class with the highest increase, from 69 to $75 \%$. (C) 2000 Elsevier Science Ltd. All rights reserved.
\end{abstract}

Keywords: Phaeodactylum tricornutum; Bacillariophyceae; Acyl lipid composition; Polyunsaturated fatty acids; Continuous culture; Cell age; Nitrogen concentration

\section{Introduction}

In a previous paper, we reported on the dramatic changes produced in the lipid profile of the diatom Phaeodactylum tricornutum Bohlin (López Alonso et al., 1998) depending on whether it was cultured indoor

\footnotetext{
* Corresponding author. Tel.: + 34-50-21-50-33; fax: + 34-950-2154-84.

E-mail address: dlopez@ualm.es (D.L. Alonso).
}

(stationary phase; batch culture) or outdoor (exponential phase; continuous culture). These changes were primarily concerned with neutral lipids (NLs) and glycolipids (GLs) that evolved in mutually opposite directions: old cells were richer in NLs and poorer in GLs than younger cells. However, the indoor and outdoor cultures were from different devices and modes of culture, thus the specific causes of the above differences in lipid profiles were difficult to assign.

Wide differences in fatty acid composition related with culture conditions are commonly observed in 


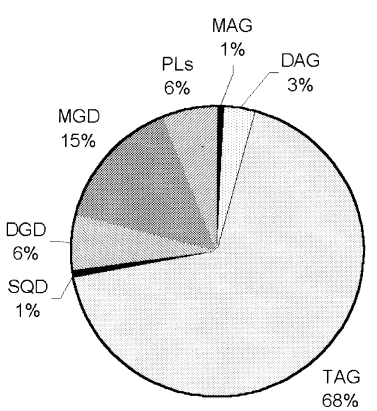

$D=0.006 h^{-1} ; t=7$ days

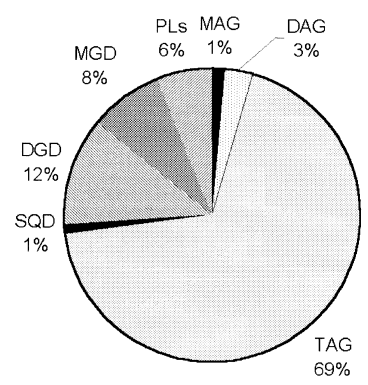

$D=0.012 h^{-1} ; t=3.5$ days

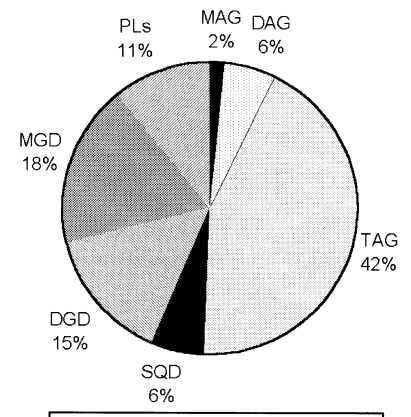

$D=0.024 h^{-1} ; t=1.75$ days

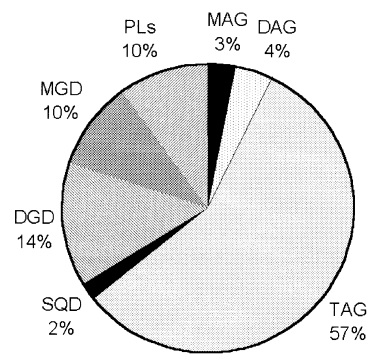

$D=0.036 h^{-1} ; t=1.15$ days
Fig. 1. Effect of the average residence time on the relative proportion of the different lipid classes.
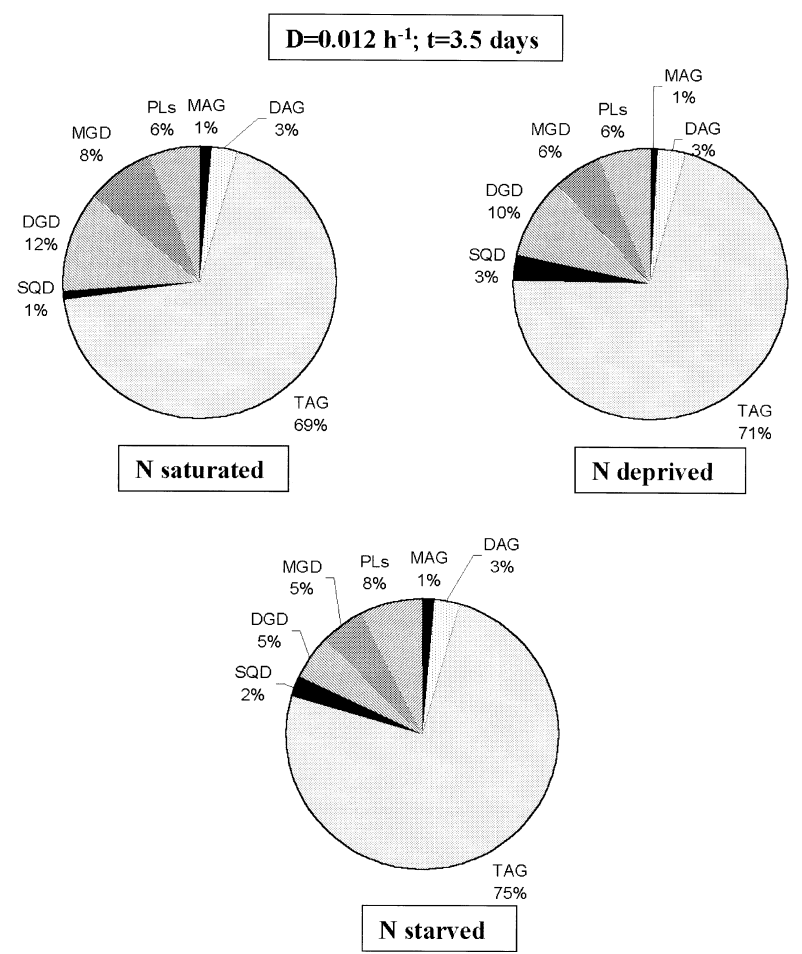

Fig. 2. Effect of nitrogen deprivation on the relative proportion of the different lipid classes at low dilution rate $\left(D=0.012 \mathrm{~h}^{-1}\right)$.
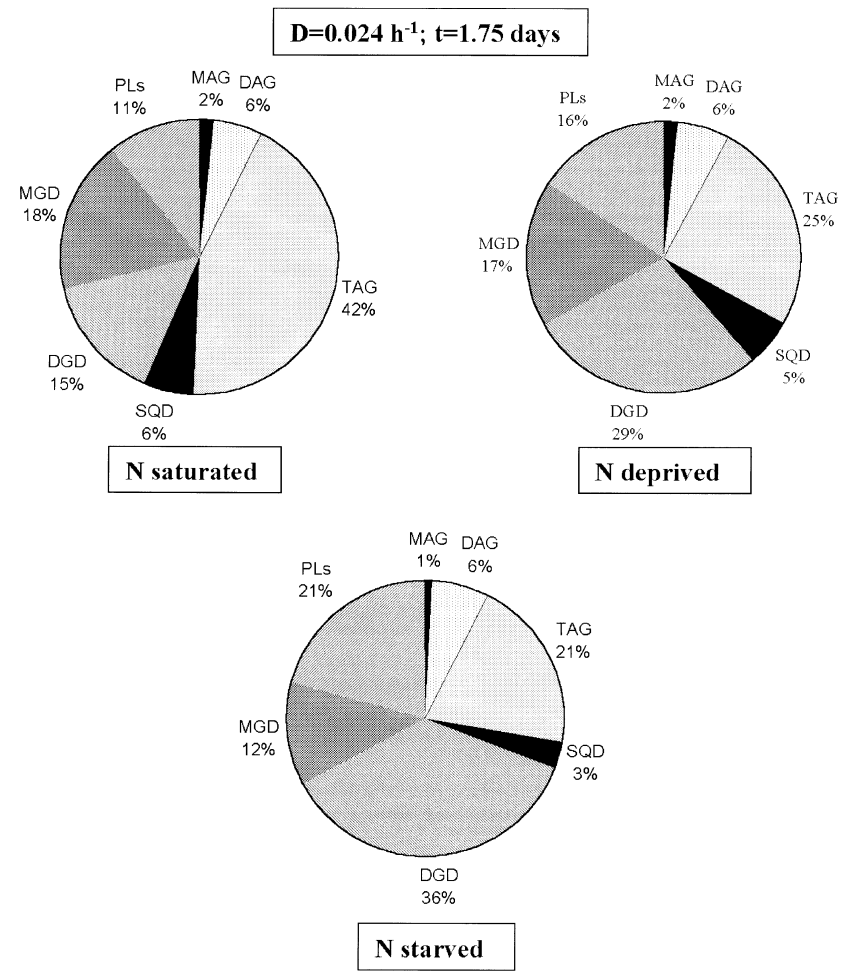

Fig. 3. Effect of nitrogen deprivation on the relative proportion of the different lipid classes at high dilution rate $\left(D=0.024 \mathrm{~h}^{-1}\right)$.

microalgae (Pohl and Zurheide, 1979; Álvarez Cobelas, 1989). Increase in lipid content is usually associated with culture ageing (i.e., stationary phase) (Piorreck and Pohl, 1984; Siron et al., 1989; Hodgson et al., 1991; Ahlgren et al., 1992; Dunstan et al., 1993; Lombardi and Wangersky, 1995; Bell and Pond, 1996; López Alonso et al., 1998). On the other hand, nitrogen stress (Pohl and Zurheide, 1979; Shifrin and Chisholm, 1980; Piorreck and Pohl, 1984; Parrish and Wangersky, 1987; Álvarez Cobelas, 1989), and nutrient limitations in general (Reitan et al., 1994) have also been positively associated with increase in lipid abundance, although the response was species-specific (Shifrin and Chisholm, 1980; Lombardi and Wangersky, 1995). Moreover, ageing effects may be indistinguishable from nutrient limitation effects because ageing generally involves depletion of some nutrient (Álvarez Cobelas, 1989) at least in batch culture which was the usual culture system in most earlier works. Also, most of these studies on microalgal lipids have focussed only on total lipids or fatty acids. For a better understanding of the changes in amounts of the individual lipid classes need to be analysed.

This study examines the effects of culture age and nitrogen availability on the lipid composition of $P$. tricornutum in steady-state continuous cultures where the effects of age and nitrogen limitation are not con- 
founded. Four different steady-states were obtained corresponding to four different dilution rates $\left(D_{1}=\right.$ $0.006 \mathrm{~h}^{-1}, D_{2}=0.012 \mathrm{~h}^{-1}, D_{3}=0.024 \mathrm{~h}^{-1}$, and $D_{4}$ $\left.=0.036 \mathrm{~h}^{-1}\right)$. The dilution rate $(D)$ is the ratio of the volumetric feed rate (fresh medium) to the total reactor volume $(51)$. Therefore, $D$ represents the volume fraction replaced per unit time while the inverse dilution rate $(1 / D)$ is the time it takes for the total reactor volume to be replaced and thus is the average time a cell spends within the reactor. At the lowest dilution rate tested $\left(D_{1}=0.006 \mathrm{~h}^{-1}\right)$ culture age was 7 days, and at the highest $\left(D_{4}=0.036 \mathrm{~h}^{-1}\right)$ culture age was 1.15 days. A broad variety of culture states was obtained under these conditions because 7 days old biomass corresponds roughly to stationary phase cultures while 1.15 days (less than $28 \mathrm{~h}$ ) are well representative of young cells. Because in a continuous culture, steady-state is only attained when the specific growth rate $\mu$ equals the dilution rate (i.e. $\mu=D$ ), the growth rate of the cells is also readily known in each experiment. At dilution rates $D_{2}$ and $D_{3}$, three nitrogen concentrations were tested: $2 \mathrm{mM}$ (N-starved), $5 \mathrm{mM}(\mathrm{N}$ deprived), and $10 \mathrm{mM}$ (N-saturated).

\section{Experimental}

The microalga used was $P$. tricornutum UTEX640. Cultures were grown in a cylindrical $(d$ $=0.17 \mathrm{~m}$ ) 5-1 computer-controlled fermentor (New Brunswick Scientific Bioflo III). Culture medium was prepared in seawater that had been filtered through $0.22 \mu \mathrm{m}$-pore Millipore filters and then autoclaved at $120^{\circ} \mathrm{C}$ for $1 \mathrm{~h}$. The medium contained sterile seawater enriched with $20 \mathrm{ml}^{-1}$ of a sterile Ukeles stock solution modified as suggested by Molina

Table 1

Lipid and fatty acid composition of $P$. tricornutum cultured at dilution rate $1\left(D=0.006 \mathrm{~h}^{-1}\right)^{\mathrm{a}}$

\begin{tabular}{|c|c|c|c|c|c|c|c|c|c|c|c|c|c|}
\hline & \multicolumn{13}{|c|}{ Lipid $^{\mathrm{b}}$ ( $\%$ of fatty acids) } \\
\hline & MAG & DAG & TAG & SQD & DGD & MGD & PI & PC & PG & PE & PLX1 & PLX2 & Biomass \\
\hline $14: 0$ & $\begin{array}{l}5.8 \\
(1.4)\end{array}$ & $\begin{array}{l}10.1 \\
(3.5)\end{array}$ & $\begin{array}{l}11.0 \\
(1.0)\end{array}$ & $\begin{array}{l}5.4 \\
(1.8)\end{array}$ & $\begin{array}{l}4.8 \\
(0.0)\end{array}$ & $\begin{array}{l}2.5 \\
(0.6)\end{array}$ & $\begin{array}{l}0.0 \\
(0.0)\end{array}$ & $\begin{array}{l}1.8 \\
(0.2)\end{array}$ & $\begin{array}{l}9.8 \\
(6.3)\end{array}$ & $\begin{array}{l}0.0 \\
(0.0)\end{array}$ & $\begin{array}{l}0.0 \\
(0.0)\end{array}$ & $\begin{array}{l}5.6 \\
(1.1)\end{array}$ & $\begin{array}{l}8.4 \\
(0.1)\end{array}$ \\
\hline $16: 0$ & $\begin{array}{l}11.7 \\
(1.0)\end{array}$ & $\begin{array}{l}7.8 \\
(0.3)\end{array}$ & $\begin{array}{l}5.3 \\
(0.2)\end{array}$ & $\begin{array}{l}30.6 \\
(8.1)\end{array}$ & $\begin{array}{l}10.5 \\
(2.0)\end{array}$ & $\begin{array}{l}6.4 \\
(0.1)\end{array}$ & $\begin{array}{l}14.0 \\
(0.0)\end{array}$ & $\begin{array}{l}4.9 \\
(2.5)\end{array}$ & $\begin{array}{l}16.6 \\
(8.4)\end{array}$ & $\begin{array}{l}20.1 \\
(1.3)\end{array}$ & $\begin{array}{l}29.4 \\
(14.4)\end{array}$ & $\begin{array}{l}19.2 \\
(1.6)\end{array}$ & $\begin{array}{l}9.4 \\
(0.1)\end{array}$ \\
\hline $16: 2 n-4$ & $\begin{array}{l}5.7 \\
(1.3)\end{array}$ & $\begin{array}{l}2.0 \\
(0.3)\end{array}$ & $\begin{array}{l}3.4 \\
(0.2)\end{array}$ & $\begin{array}{l}0.0 \\
(0.0)\end{array}$ & $\begin{array}{l}5.9 \\
(4.2)\end{array}$ & $\begin{array}{l}9.1 \\
(0.2)\end{array}$ & $\begin{array}{l}0.0 \\
(0.0)\end{array}$ & $\begin{array}{l}2.0 \\
(0.5)\end{array}$ & $\begin{array}{l}1.9 \\
(1.9)\end{array}$ & $\begin{array}{l}18.2 \\
(18.2)\end{array}$ & $\begin{array}{l}0.0 \\
(0.0)\end{array}$ & $\begin{array}{l}3.2 \\
(3.2)\end{array}$ & $\begin{array}{l}3.8 \\
(0.0)\end{array}$ \\
\hline $16: 3 n-4$ & $\begin{array}{l}14.1 \\
(1.3)\end{array}$ & $\begin{array}{l}7.9 \\
(0.1)\end{array}$ & $\begin{array}{l}4.6 \\
(0.1)\end{array}$ & $\begin{array}{l}2.2 \\
(2.2)\end{array}$ & $\begin{array}{l}18.3 \\
(2.0)\end{array}$ & $\begin{array}{l}26.7 \\
(0.1)\end{array}$ & $\begin{array}{l}0.0 \\
(0.0)\end{array}$ & $\begin{array}{l}0.5 \\
(0.5)\end{array}$ & $\begin{array}{l}6.3 \\
(6.3)\end{array}$ & $\begin{array}{l}0.0 \\
(0.0)\end{array}$ & $\begin{array}{l}0.0 \\
(0.0)\end{array}$ & $\begin{array}{l}4.3 \\
(0.5)\end{array}$ & $\begin{array}{l}8.2 \\
(0.2)\end{array}$ \\
\hline $16: 4 n-1$ & $\begin{array}{l}0.0 \\
(0.0)\end{array}$ & $\begin{array}{l}0.0 \\
(0.0)\end{array}$ & $\begin{array}{l}0.2 \\
(0.0)\end{array}$ & $\begin{array}{l}0.0 \\
(0.0)\end{array}$ & $\begin{array}{l}0.2 \\
(0.2)\end{array}$ & $\begin{array}{l}0.7 \\
(0.1)\end{array}$ & $\begin{array}{l}0.0 \\
(0.0)\end{array}$ & $\begin{array}{l}0.0 \\
(0.0)\end{array}$ & $\begin{array}{l}0.0 \\
(0.0)\end{array}$ & $\begin{array}{l}0.0 \\
(0.0)\end{array}$ & $\begin{array}{l}0.0 \\
(0.0)\end{array}$ & $\begin{array}{l}0.0 \\
(0.0)\end{array}$ & $\begin{array}{l}0.3 \\
(0.0)\end{array}$ \\
\hline $18: \ln -7$ & $\begin{array}{l}0.0 \\
(0.0)\end{array}$ & $\begin{array}{l}0.0 \\
(0.0)\end{array}$ & $\begin{array}{l}0.3 \\
(0.0)\end{array}$ & $\begin{array}{l}0.0 \\
(0.0)\end{array}$ & $\begin{array}{l}1.0 \\
(0.4)\end{array}$ & $\begin{array}{l}0.5 \\
(0.1)\end{array}$ & $\begin{array}{l}0.8 \\
(0.9)\end{array}$ & $\begin{array}{l}1.0 \\
(0.1)\end{array}$ & $\begin{array}{l}0.0 \\
(0.0)\end{array}$ & $\begin{array}{l}0.0 \\
(0.0)\end{array}$ & $\begin{array}{l}0.0 \\
(0.0)\end{array}$ & $\begin{array}{l}0.0 \\
(0.0)\end{array}$ & $\begin{array}{l}0.5 \\
(0.0)\end{array}$ \\
\hline $18: 2 n-6$ & $\begin{array}{l}2.9 \\
(0.0)\end{array}$ & $\begin{array}{l}1.0 \\
(0.3)\end{array}$ & $\begin{array}{l}1.3 \\
(0.0)\end{array}$ & $\begin{array}{l}6.2 \\
(1.3)\end{array}$ & $\begin{array}{l}4.5 \\
(2.7)\end{array}$ & $\begin{array}{l}3.3 \\
(0.1)\end{array}$ & $\begin{array}{l}20.4 \\
(3.0)\end{array}$ & $\begin{array}{l}20.8 \\
(2.4)\end{array}$ & $\begin{array}{l}12.2 \\
(1.0)\end{array}$ & $\begin{array}{l}9.8 \\
(9.8)\end{array}$ & $\begin{array}{l}4.6 \\
(4.6)\end{array}$ & $\begin{array}{l}10.8 \\
(3.5)\end{array}$ & $\begin{array}{l}2.6 \\
(0.0)\end{array}$ \\
\hline $20: 4 n-6$ & $\begin{array}{l}0.0 \\
(0.0)\end{array}$ & $\begin{array}{l}0.0 \\
(0.0)\end{array}$ & $\begin{array}{l}1.0 \\
(0.0)\end{array}$ & $\begin{array}{l}0.0 \\
(0.0)\end{array}$ & $\begin{array}{l}0.5 \\
(0.1)\end{array}$ & $\begin{array}{l}0.4 \\
(0.0)\end{array}$ & $\begin{array}{l}0.9 \\
(0.9)\end{array}$ & $\begin{array}{l}2.6 \\
(0.3)\end{array}$ & $\begin{array}{l}0.0 \\
(0.0)\end{array}$ & $\begin{array}{l}0.0 \\
(0.0)\end{array}$ & $\begin{array}{l}0.0 \\
(0.0)\end{array}$ & $\begin{array}{l}0.0 \\
(0.0)\end{array}$ & $\begin{array}{l}0.9 \\
(0.0)\end{array}$ \\
\hline $20: 5 n-3$ & $\begin{array}{l}21.2 \\
(1.5)\end{array}$ & $\begin{array}{l}8.3 \\
(1.8)\end{array}$ & $\begin{array}{l}35.5 \\
(0.3)\end{array}$ & $\begin{array}{l}1.8 \\
(1.8)\end{array}$ & $\begin{array}{l}13.2 \\
(5.2)\end{array}$ & $\begin{array}{l}8.8 \\
(0.1)\end{array}$ & $\begin{array}{l}8.0 \\
(1.1)\end{array}$ & $\begin{array}{l}8.8 \\
(0.2)\end{array}$ & $\begin{array}{l}7.5 \\
(7.5)\end{array}$ & $\begin{array}{l}18.3 \\
(0.1)\end{array}$ & $\begin{array}{l}5.7 \\
(5.7)\end{array}$ & $\begin{array}{l}8.2 \\
(1.6)\end{array}$ & $\begin{array}{l}25.7 \\
(0.2)\end{array}$ \\
\hline $22: 6 n-3$ & $\begin{array}{l}2.7 \\
(0.1)\end{array}$ & $\begin{array}{l}0.4 \\
(0.4)\end{array}$ & $\begin{array}{l}0.6 \\
(0.1)\end{array}$ & $\begin{array}{l}1.8 \\
(1.8)\end{array}$ & $\begin{array}{l}2.1 \\
(1.2)\end{array}$ & $\begin{array}{l}1.7 \\
(0.1)\end{array}$ & $\begin{array}{l}7.8 \\
(1.0)\end{array}$ & $\begin{array}{l}10.9 \\
(1.0)\end{array}$ & $\begin{array}{l}3.0 \\
(3.0)\end{array}$ & $\begin{array}{l}0.0 \\
(0.0)\end{array}$ & $\begin{array}{l}0.0 \\
(0.0)\end{array}$ & $\begin{array}{l}2.0 \\
(2.0)\end{array}$ & $\begin{array}{l}1.8 \\
(0.1)\end{array}$ \\
\hline $\mathrm{USCFAs}^{\mathrm{c}}$ & $\begin{array}{l}7.1 \\
(1.0)\end{array}$ & $\begin{array}{l}51.7 \\
(7.9)\end{array}$ & $\begin{array}{l}8.1 \\
(2.2)\end{array}$ & $\begin{array}{l}0.0 \\
(0.0)\end{array}$ & $\begin{array}{l}0.0 \\
(0.0)\end{array}$ & $\begin{array}{l}1.9 \\
(0.2)\end{array}$ & $\begin{array}{l}0.0 \\
(0.0)\end{array}$ & $\begin{array}{l}0.0 \\
(0.0)\end{array}$ & $\begin{array}{l}0.0 \\
(0.0)\end{array}$ & $\begin{array}{l}0.0 \\
(0.0)\end{array}$ & $\begin{array}{l}4.9 \\
(4.9)\end{array}$ & $\begin{array}{l}5.3 \\
(2.5)\end{array}$ & $\begin{array}{l}6.3 \\
(0.1)\end{array}$ \\
\hline Others & 4.3 & 1.3 & 3.2 & 8.4 & 4.4 & 8.7 & 10.8 & 14.6 & 8.8 & 0.0 & 33.5 & 20.9 & 5.4 \\
\hline
\end{tabular}

${ }^{a}$ Values are averages of three independent measurements. Standard errors are shown in parentheses.

${ }^{\mathrm{b}}$ MAG, DAG and TAG stated for mono-, di-, and triacylglycerols, respectively; SQD, DGD, and MGD stated for sulfoquinovosyl-, digalactosyl-, and monogalactosyldiacylglycerols, respectively; PI, PC, PG, and PE stated for phosphatidylinositol, -choline, -glycerol, and -ethanolamine, respectively; PLX are unknown phospholipids.

${ }^{\mathrm{c}}$ USCFAs = unknown short-chain fatty acids. For additional details see López Alonso et al. (1998). 
Grima et al. (1994). Nitrogen concentration was changed by decreasing the quantity of sodium nitrate used to prepare the stock solution to one-half $(5 \mathrm{mM})$ and one-fifth $(2 \mathrm{mM})$ of the original content. While the original composition was saturating for nitrogen in the culture conditions used, the one-half reduced concentration was intended to cause a slight deprivation and the one-fifth reduced concentration was intended to produce a severe nitrogen limitation.

The culture was illuminated by six cool-white fluorescent lamps (Osram Dulux EL, $20 \mathrm{~W}$ ) regularly spaced around the culture vessel. This produced a scalar irradiance of $1200 \mu \mathrm{E} \cdot \mathrm{m}^{-2} \cdot \mathrm{s}^{-1}$ (PAR) throughout the culture. Irradiance was measured with a Quantum Scalar Irradiance Meter QSL-100 Biospherical Instruments Laboratory (San Diego, CA). Temperature was kept at $20^{\circ} \mathrm{C}$. The air supply was sterilized by filtration through $0.22 \mu \mathrm{m}$ Millipore filters at a rate of $1.51 \cdot \mathrm{min}^{-1}$. Agitation speed was set at $150 \mathrm{rpm}$ and the $\mathrm{pH}$ was maintained constant at 8 by on-demand injection of pure $\mathrm{CO}_{2}$ mixed with the air supply.

The experiments were done in continuous mode. For this, the cultures were started in batch mode with an initial addition of $P$. tricornutum inoculum to 51 medium contained in the photobioreactor to give a starting biomass concentration of around 50 $\mathrm{mg} \cdot \mathrm{l}^{-1}$. The cultures were then kept in batch mode until a biomass concentration of $500-700 \mathrm{mg} \cdot \mathrm{l}^{-1}$ was attained and then the continuous operation was started by adding continuously the fresh medium. The dilution rate, $D$, for each experiment was set using a programmable peristaltic pump. The cultures were then developed until a steady-state was attained. At each steadystate the runtime was at least 4 days. The biomass was then harvested by centrifugation.

Four different steady-states were obtained at four different dilution rates $\left(D_{1}=0.006 \mathrm{~h}^{-1}, D_{2}=0.012\right.$ $\mathrm{h}^{-1}, D_{3}=0.024 \mathrm{~h}^{-1}$, and $\left.D_{4}=0.036 \mathrm{~h}^{-1}\right)$. Average

Table 2

Lipid and fatty acid composition of $P$. tricornutum cultured at dilution rate $2\left(D=0.012 \mathrm{~h}^{-1}\right)^{\mathrm{a}}$

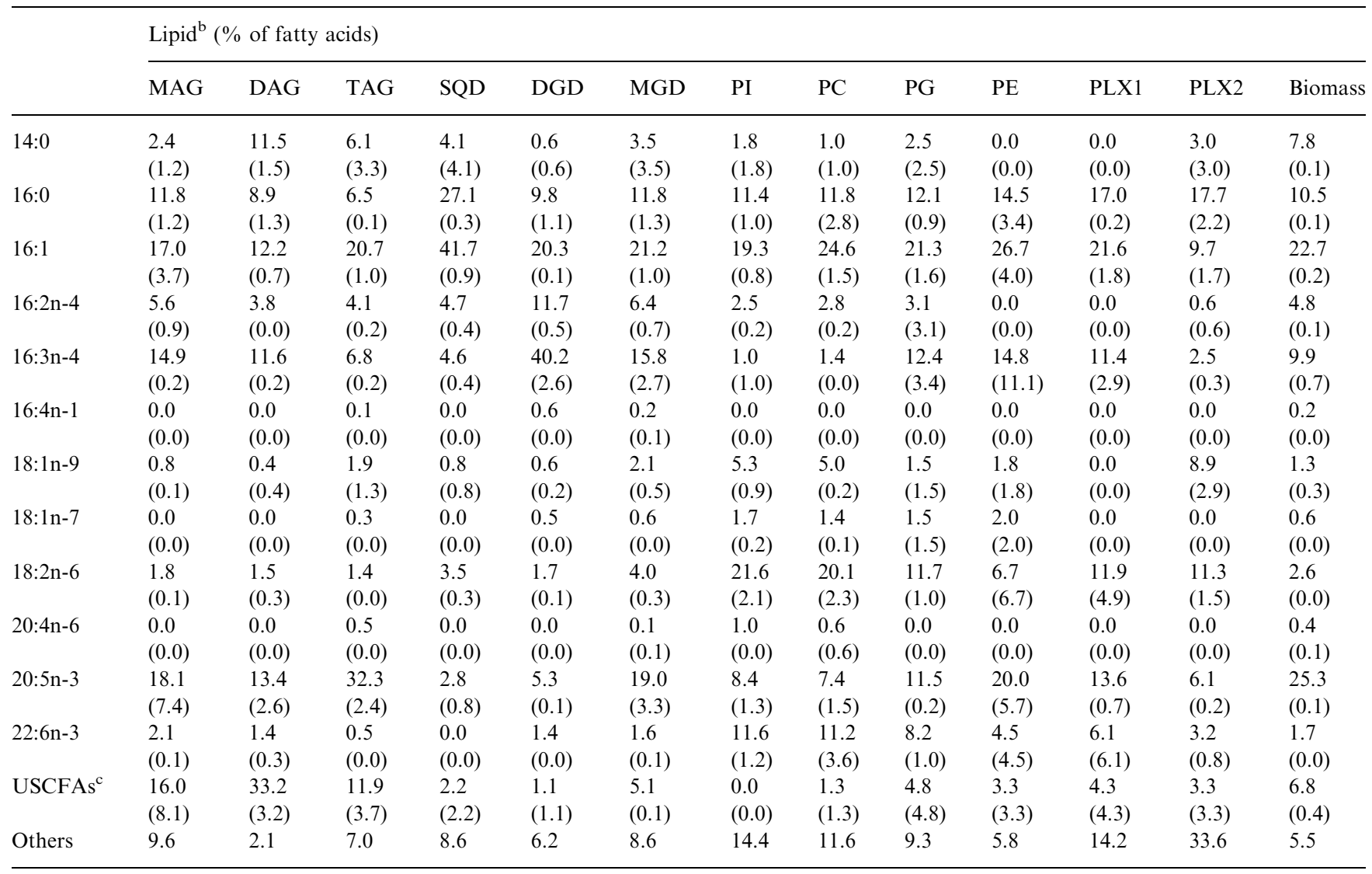

${ }^{a}$ Values are averages of three independent measurements. Standard errors are shown in parentheses.

${ }^{\mathrm{b}}$ MAG, DAG and TAG stated for mono-, di-, and triacylglycerols, respectively; SQD, DGD, and MGD stated for sulfoquinovosyl-, digalactosyl-, and monogalactosyldiacylglycerols, respectively; PI, PC, PG, and PE stated for phosphatidylinositol, -choline, -glycerol, and -ethanolamine, respectively; PLX are unknown phospholipids.

${ }^{\mathrm{c}}$ USCFAs = unknown short-chain fatty acids. For additional details see López Alonso et al. (1998). 
cell ages were $7,3.50,1.75$, and 1.15 days at $D_{1}, D_{2}$, $D_{3}$, and $D_{4}$, respectively. At the two near-optimal dilution rates $\left(D_{2}\right.$ and $D_{3}$, experiments were carried out also at one-half and one-fifth of the standard nitrogen concentration. Overall, eight different steady-states (experiments) were attained and analysed.

Biomass concentration in the culture was estimated by optical density (Molina Grima et al., 1993) and checked under steady-state conditions by dry weight determinations. Fatty acid and lipid class analyses were done as described elsewhere (López Alonso et al., 1998). Values for 16:1 probably included two isomers $(16: 1 \mathrm{n} 7$ and $16: 1 \mathrm{n} 13$ trans $)$ in the case of the plastidial lipid class PG (López Alonso et al., 1998).

For each steady-state, three samples of biomass were extracted and analysed separately. The data were averaged.

\section{Results and discussion}

The data presented were obtained using microalgal biomass harvested from steady-state continuous cultures. The data refer exclusively to acyl lipids and the discussion is restricted to the main fatty acids (those that constitute $5 \%$ or more of total fatty acids) that can be reliably estimated. These fatty acids were 14:0, 16:0, 16:1, 16:2, 16:3, and 20:5. The corresponding result compositions are reported in Tables $1-8$ for various conditions.

\subsection{Changes related with culture age}

\subsubsection{Fatty acid composition}

Only slight changes appeared in the fatty acid composition of $P$. tricornutum biomass when the culture

Table 3

Lipid and fatty acid composition of $P$. tricornutum cultured at dilution rate $3\left(D=0.024 \mathrm{~h}^{-1}\right)^{\mathrm{a}}$

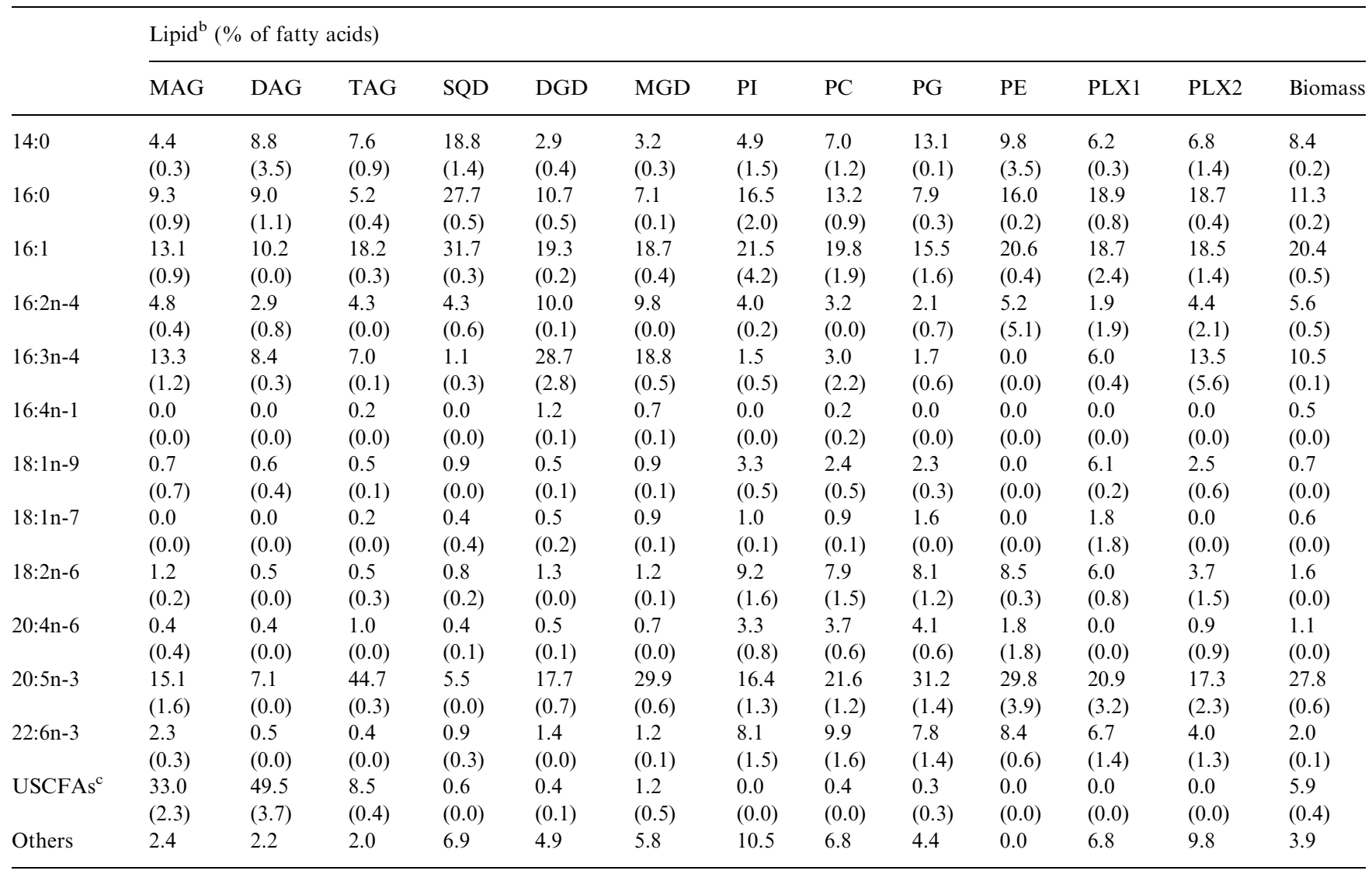

${ }^{a}$ Values are averages of three independent measurements. Standard errors are shown in parentheses.

${ }^{\mathrm{b}}$ MAG, DAG and TAG stated for mono-, di-, and triacylglycerols, respectively; SQD, DGD, and MGD stated for sulfoquinovosyl-, digalactosyl-, and monogalactosyldiacylglycerols, respectively; PI, PC, PG, and PE stated for phosphatidylinositol, -choline, -glycerol, and -ethanolamine, respectively; PLX are unknown phospholipids.

${ }^{\mathrm{c}}$ USCFAs = unknown short-chain fatty acids. For additional details see López Alonso et al. (1998). 
age changed (Tables 1-4). The observed trends were a moderate increase of 16:0, 16:3, and 20:5 and a decrease in 16:1 from older (Table 1) to younger cells (Table 4). Note that $16: 1$ and $20: 5$ are the two major fatty acids in this microalga, together accounting for ca. $50 \%$ of total fatty acids. As the total fatty acid content did not change, and was always around $11 \%$ of dry weight (data not shown), the youngest cells produce a litle more 16:0,16:3, and 20:5 at the expense of 16:1. This pattern was not consistently seen in all the major acyl lipid classes. For example, for DGD, when dilution rate was increased (age decreased) 16:1 declined from 33 to $16 \%, 16: 0$ increased moderately from 10 to $14 \%, 20: 5$ decreased slightly from 13 to $8 \%$, and $16: 3$ increased dramatically from 18 to $36 \%$ (Tables 1-4). Meanwhile, for the other major galactolipid, MGD, 16:1 again decreased from 28 to $18 \%, 16: 0$ increased from 6 to $12 \%, 20: 5$ content increased substantially from 9 to $25 \%$, but $16: 3$ decreased from 27 to $15 \%$ (Tables $1-4$ ). Therefore, the overall fatty acid changes elicited by cell ageing were different for different lipid classes (Tables 1-4). This also suggests that the synthesis of polyunsaturates is more active in young fast growing cells which are building up their photosynthetic apparatus made up chiefly of membranes rich in PUFAs (Gurr and Harwood, 1991). Additionally, these results suggest that DGD is the substrate for the desaturase in the synthesis of $16: 3$ from 16:1.

\subsubsection{Lipid class composition}

Average cell age had a stronger impact on lipid classes as can be seen in Fig. 1. Triacylglycerols (TAG), for instance, ranged between 42 and $69 \%$ showing the lowest value at $D_{3}$ (average cell age 1.75 days) (Fig. 1). GLs oscillated between 20 and $40 \%$ the highest value appearing at $D_{3}$ (Fig. 1). The content in polar lipids in general tended to increase at the highest

Table 4

Lipid and fatty acid composition of $P$. tricornutum cultured at dilution rate $4\left(D=0.036 \mathrm{~h}^{-1}\right)^{\mathrm{a}}$

\begin{tabular}{|c|c|c|c|c|c|c|c|c|c|c|c|c|c|}
\hline & \multicolumn{13}{|c|}{ Lipid $^{\mathrm{b}}$ (\% of fatty acids) } \\
\hline & MAG & DAG & TAG & SQD & DGD & MGD & PI & PC & PG & PE & PLX1 & PLX2 & Biomass \\
\hline $14: 0$ & $\begin{array}{l}9.8 \\
(0.0)\end{array}$ & $\begin{array}{l}7.7 \\
(2.1)\end{array}$ & $\begin{array}{l}8.3 \\
(0.0)\end{array}$ & $\begin{array}{l}12.2 \\
(1.8)\end{array}$ & $\begin{array}{l}3.4 \\
(0.3)\end{array}$ & $\begin{array}{l}5.7 \\
(0.1)\end{array}$ & $\begin{array}{l}2.2 \\
(0.1)\end{array}$ & $\begin{array}{l}6.8 \\
(1.4)\end{array}$ & $\begin{array}{l}4.6 \\
(0.9)\end{array}$ & $\begin{array}{l}6.7 \\
(1.6)\end{array}$ & $\begin{array}{l}1.1 \\
(1.1)\end{array}$ & $\begin{array}{l}7.6 \\
(0.0)\end{array}$ & $\begin{array}{l}7.6 \\
(0.2)\end{array}$ \\
\hline $16: 0$ & $\begin{array}{l}12.4 \\
(0.5)\end{array}$ & $\begin{array}{l}11.2 \\
(0.7)\end{array}$ & $\begin{array}{l}5.8 \\
(0.4)\end{array}$ & $\begin{array}{l}33.2 \\
(0.2)\end{array}$ & $\begin{array}{l}14.1 \\
(0.4)\end{array}$ & $\begin{array}{l}12.2 \\
(0.5)\end{array}$ & $\begin{array}{l}16.1 \\
(0.9)\end{array}$ & $\begin{array}{l}17.3 \\
(2.0)\end{array}$ & $\begin{array}{l}15.0 \\
(0.5)\end{array}$ & $\begin{array}{l}13.9 \\
(5.4)\end{array}$ & $\begin{array}{l}17.9 \\
(5.3)\end{array}$ & $\begin{array}{l}14.4 \\
(1.9)\end{array}$ & $\begin{array}{l}12.9 \\
(0.3)\end{array}$ \\
\hline $16: 2 n-4$ & $\begin{array}{l}6.0 \\
(1.3)\end{array}$ & $\begin{array}{l}4.0 \\
(0.3)\end{array}$ & $\begin{array}{l}5.0 \\
(0.2)\end{array}$ & $\begin{array}{l}10.6 \\
(2.7)\end{array}$ & $\begin{array}{l}9.0 \\
(0.3)\end{array}$ & $\begin{array}{l}7.8 \\
(0.5)\end{array}$ & $\begin{array}{l}5.2 \\
(1.4)\end{array}$ & $\begin{array}{l}3.3 \\
(0.7)\end{array}$ & $\begin{array}{l}3.1 \\
(1.3)\end{array}$ & $\begin{array}{l}7.8 \\
(7.8)\end{array}$ & $\begin{array}{l}3.6 \\
(3.6)\end{array}$ & $\begin{array}{l}5.0 \\
(2.8)\end{array}$ & $\begin{array}{l}5.5 \\
(0.5)\end{array}$ \\
\hline $16: 3 n-4$ & $\begin{array}{l}15.9 \\
(1.1)\end{array}$ & $\begin{array}{l}10.2 \\
(0.0)\end{array}$ & $\begin{array}{l}6.5 \\
(0.1)\end{array}$ & $\begin{array}{l}2.8 \\
(0.1)\end{array}$ & $\begin{array}{l}36.3 \\
(0.4)\end{array}$ & $\begin{array}{l}15.4 \\
(0.3)\end{array}$ & $\begin{array}{l}1.6 \\
(0.2)\end{array}$ & $\begin{array}{l}1.0 \\
(0.0)\end{array}$ & $\begin{array}{l}2.9 \\
(0.6)\end{array}$ & $\begin{array}{l}1.6 \\
(1.5)\end{array}$ & $\begin{array}{l}17.9 \\
(17.9)\end{array}$ & $\begin{array}{l}3.2 \\
(1.2)\end{array}$ & $\begin{array}{l}10.8 \\
(0.2)\end{array}$ \\
\hline $16: 4 n-1$ & $\begin{array}{l}1.2 \\
(0.2)\end{array}$ & $\begin{array}{l}0.7 \\
(0.0)\end{array}$ & $\begin{array}{l}0.4 \\
(0.0)\end{array}$ & $\begin{array}{l}0.0 \\
(0.0)\end{array}$ & $\begin{array}{l}3.3 \\
(0.1)\end{array}$ & $\begin{array}{l}1.4 \\
(0.0)\end{array}$ & $\begin{array}{l}0.0 \\
(0.0)\end{array}$ & $\begin{array}{l}0.0 \\
(0.0)\end{array}$ & $\begin{array}{l}0.0 \\
(0.0)\end{array}$ & $\begin{array}{l}0.0 \\
(0.0)\end{array}$ & $\begin{array}{l}1.5 \\
(1.5)\end{array}$ & $\begin{array}{l}0.0 \\
(0.0)\end{array}$ & $\begin{array}{l}0.9 \\
(0.0)\end{array}$ \\
\hline $18: 1 n-7$ & $\begin{array}{l}0.0 \\
(0.0)\end{array}$ & $\begin{array}{l}0.0 \\
(0.0)\end{array}$ & $\begin{array}{l}0.3 \\
(0.0)\end{array}$ & $\begin{array}{l}0.7 \\
(0.0)\end{array}$ & $\begin{array}{l}0.6 \\
(0.1)\end{array}$ & $\begin{array}{l}0.6 \\
(0.4)\end{array}$ & $\begin{array}{l}0.8 \\
(0.0)\end{array}$ & $\begin{array}{l}1.0 \\
(0.0)\end{array}$ & $\begin{array}{l}0.8 \\
(0.8)\end{array}$ & $\begin{array}{l}0.9 \\
(0.9)\end{array}$ & $\begin{array}{l}0.0 \\
(0.0)\end{array}$ & $\begin{array}{l}2.6 \\
(2.6)\end{array}$ & $\begin{array}{l}0.6 \\
(0.0)\end{array}$ \\
\hline $18: 2 n-6$ & $\begin{array}{l}1.1 \\
(0.1)\end{array}$ & $\begin{array}{l}0.7 \\
(0.2)\end{array}$ & $\begin{array}{l}0.8 \\
(0.1)\end{array}$ & $\begin{array}{l}1.4 \\
(0.1)\end{array}$ & $\begin{array}{l}0.7 \\
(0.1)\end{array}$ & $\begin{array}{l}1.4 \\
(0.5)\end{array}$ & $\begin{array}{l}9.5 \\
(0.1)\end{array}$ & $\begin{array}{l}6.1 \\
(0.8)\end{array}$ & $\begin{array}{l}3.2 \\
(0.2)\end{array}$ & $\begin{array}{l}1.9 \\
(1.9)\end{array}$ & $\begin{array}{l}0.0 \\
(0.0)\end{array}$ & $\begin{array}{l}6.4 \\
(4.9)\end{array}$ & $\begin{array}{l}1.5 \\
(0.0)\end{array}$ \\
\hline $20: 4 n-6$ & $\begin{array}{l}0.8 \\
(0.2)\end{array}$ & $\begin{array}{l}0.6 \\
(0.0)\end{array}$ & $\begin{array}{l}1.0 \\
(0.0)\end{array}$ & $\begin{array}{l}0.0 \\
(0.0)\end{array}$ & $\begin{array}{l}0.2 \\
(0.1)\end{array}$ & $\begin{array}{l}0.7 \\
(0.0)\end{array}$ & $\begin{array}{l}3.8 \\
(0.1)\end{array}$ & $\begin{array}{l}3.4 \\
(0.5)\end{array}$ & $\begin{array}{l}1.8 \\
(0.0)\end{array}$ & $\begin{array}{l}1.2 \\
(1.2)\end{array}$ & $\begin{array}{l}0.0 \\
(0.0)\end{array}$ & $\begin{array}{l}0.4 \\
(0.4)\end{array}$ & $\begin{array}{l}1.1 \\
(0.0)\end{array}$ \\
\hline $20: 5 n-3$ & $\begin{array}{l}6.9 \\
(0.9)\end{array}$ & $\begin{array}{l}14.5 \\
(0.3)\end{array}$ & $\begin{array}{l}43.8 \\
(0.9)\end{array}$ & $\begin{array}{l}2.7 \\
(0.2)\end{array}$ & $\begin{array}{l}8.3 \\
(1.1)\end{array}$ & $\begin{array}{l}24.8 \\
(2.4)\end{array}$ & $\begin{array}{l}19.2 \\
(0.9)\end{array}$ & $\begin{array}{l}20.4 \\
(1.8)\end{array}$ & $\begin{array}{l}32.1 \\
(13.9)\end{array}$ & $\begin{array}{l}38.7 \\
(16.5)\end{array}$ & $\begin{array}{l}20.8 \\
(13.0)\end{array}$ & $\begin{array}{l}18.7 \\
(2.8)\end{array}$ & $\begin{array}{l}29.0 \\
(0.6)\end{array}$ \\
\hline $22: 6 n-3$ & $\begin{array}{l}2.2 \\
(0.2)\end{array}$ & $\begin{array}{l}3.4 \\
(1.6)\end{array}$ & $\begin{array}{l}0.5 \\
(0.0)\end{array}$ & $\begin{array}{l}1.7 \\
(0.2)\end{array}$ & $\begin{array}{l}1.7 \\
(0.4)\end{array}$ & $\begin{array}{l}1.5 \\
(0.1)\end{array}$ & $\begin{array}{l}14.1 \\
(0.8)\end{array}$ & $\begin{array}{l}15.9 \\
(2.4)\end{array}$ & $\begin{array}{l}19.0 \\
(11.1)\end{array}$ & $\begin{array}{l}7.2 \\
(2.3)\end{array}$ & $\begin{array}{l}13.5 \\
(2.5)\end{array}$ & $\begin{array}{l}6.3 \\
(3.1)\end{array}$ & $\begin{array}{l}2.5 \\
(0.1)\end{array}$ \\
\hline $\mathrm{USCFAs}^{\mathrm{c}}$ & $\begin{array}{l}27.9 \\
(7.3)\end{array}$ & $\begin{array}{l}31.1 \\
(0.1)\end{array}$ & $\begin{array}{l}7.5 \\
(0.7)\end{array}$ & $\begin{array}{l}0.5 \\
(0.5)\end{array}$ & $\begin{array}{l}0.2 \\
(0.1)\end{array}$ & $\begin{array}{l}2.1 \\
(1.0)\end{array}$ & $\begin{array}{l}0.0 \\
(0.0)\end{array}$ & $\begin{array}{l}0.4 \\
(0.0)\end{array}$ & $\begin{array}{l}1.9 \\
(1.9)\end{array}$ & $\begin{array}{l}1.0 \\
(0.9)\end{array}$ & $\begin{array}{l}0.0 \\
(0.0)\end{array}$ & $\begin{array}{l}4.6 \\
(4.6)\end{array}$ & $\begin{array}{l}5.3 \\
(0.1)\end{array}$ \\
\hline Others & 2.6 & 1.9 & 2.7 & 5.8 & 6.2 & 6.5 & 11.3 & 8.1 & 1.5 & 3.4 & 7.3 & 12.3 & 4.0 \\
\hline
\end{tabular}

${ }^{a}$ Values are averages of three independent measurements. Standard errors are shown in parentheses.

${ }^{\mathrm{b}}$ MAG, DAG and TAG stated for mono-, di-, and triacylglycerols, respectively; SQD, DGD, and MGD stated for sulfoquinovosyl-, digalactosyl-, and monogalactosyldiacylglycerols, respectively; PI, PC, PG, and PE stated for phosphatidylinositol, -choline, -glycerol, and -ethanolamine, respectively; PLX are unknown phospholipids.

${ }^{\mathrm{c}}$ USCFAs = unknown short-chain fatty acids. For additional details see López Alonso et al. (1998). 
dilution rates (youngest cells) but there was considerable fluctuations around this general trend. Extreme values for all lipids were found at $D_{3}$ which seems to represent a 'limit' steady-state. Polar lipids in general, and, particularly, main galactolipids (MGD and DGD) showed their highest values at this state. Because polar lipids are membrane lipids (Gurr and Harwood, 1991) this suggests that, at $D_{3}$ dilution rate, the cells contained a higher proportion of membranes (especially chloroplast membranes). Probably, this state represents an 'optimum' for $P$. tricornutum cells as suggested by the fact that biomass productivity reached a maximum at this dilution rate; the biomass productivity decreased when culture was moved in either direction from this optimum point (data not shown).

A reduction in polar lipids and an increase in TAG are usually associated with culture ageing (Álvarez Cobelas, 1989; Hodgson et al., 1991; Dun- stan et al., 1993; Lombardi and Wangersky, 1995; Brown et al., 1996), however, the specific response may be different in different microalgae (Lombardi and Wangersky, 1995), or the response may depend on the steady state reached as shown in this work. When dilution rate increases (i.e. age decreases) there is an increase in polar lipids but up to a limit ( $D_{3}$ in our case). If this limiting dilution rate is exceeded the trend is reversed.

These changes in lipid profiles can be attributed to two opposing factors which always change simultaneously in continuous cultures: a high dilution rate that gives rise to low biomass concentration and an increase in light availability because of a decrease in mutual shadowing of cells (Molina Grima et al., 1994). Therefore, as $D$ is incremented, the average light a cell receives is also increased and this reduces the need for a large photosynthetic apparatus to harvest light. Increase in light availability apparently reduces the ac-

Table 5

Lipid and fatty acid composition of $P$. tricornutum cultured at dilution rate $2\left(D=0.012 \mathrm{~h}^{-1}\right)$ and half nitrogen concentration $(5 \mathrm{mmol})^{\mathrm{a}}$

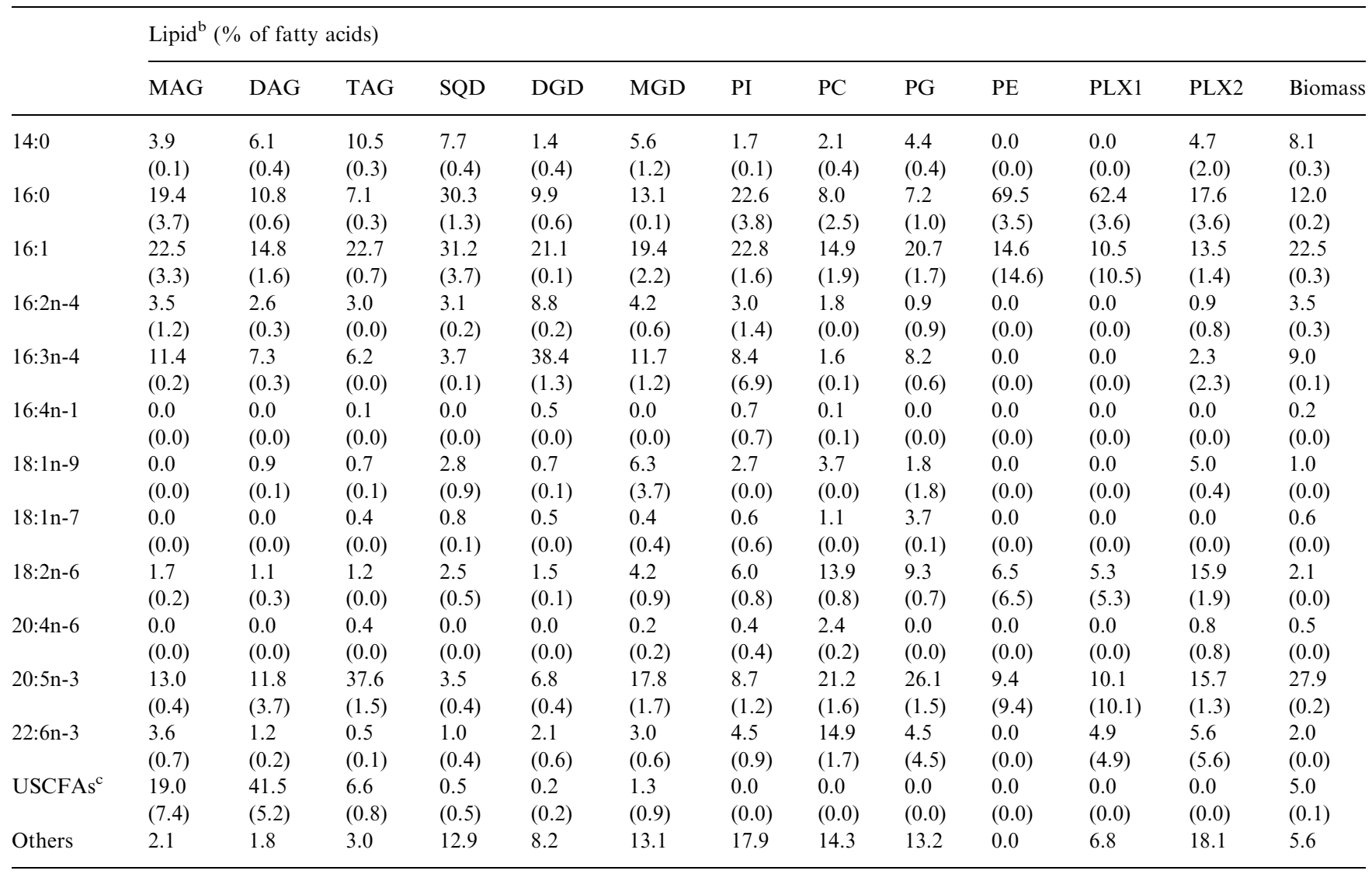

${ }^{a}$ Values are averages of three independent measurements. Standard errors are shown in parentheses.

${ }^{\mathrm{b}}$ MAG, DAG and TAG stated for mono-, di-, and triacylglycerols, respectively; SQD, DGD, and MGD stated for sulfoquinovosyl-, digalactosyl-, and monogalactosyldiacylglycerols, respectively; PI, PC, PG, and PE stated for phosphatidylinositol, -choline, -glycerol, and -ethanolamine, respectively; PLX are unknown phospholipids.

${ }^{\mathrm{c}}$ USCFAs = unknown short-chain fatty acids. For additional details see López Alonso et al. (1998). 
cumulation of polar lipids in membranes. This occurs, for example, when $D$ is increased from 0.024 to 0.036 $\mathrm{h}^{-1}$.

\subsection{Changes related with nitrogen concentration}

At two dilution rates $\left(D_{2}\right.$ and $\left.D_{3}\right)$ we assayed also the effect of nitrogen concentration on lipid composition (see Section 2). In addition to the nitrogen concentration supplied by the standard medium used, (high enough to support a nitrogen-saturated, photolimited growth), we also investigated one-half $(1 / 2)$ and one-fifth $(1 / 5)$ of the standard nitrogen concentrations (Tables 5-8), as detailed earlier. At half the standard nitrogen concentration the culture was slightly deprived whereas at $1 / 5$ of the standard concentration the culture was starved, as observed by a decrease in the steady-state biomass concentration (data not shown).

\subsubsection{Fatty acid composition}

At dilution rate $D_{2}$, with the nitrogen supply reduced to $1 / 2$ of the standard, only minor changes took place (compare Tables 2 and 5) but major ones arose when the nitrogen supply was subsequently reduced to $1 / 5$ of the concentration in the standard medium (compare Tables 2 and 6). For example, the 16:0 content in the biomass increased from 10 to $27 \%$, while 16:1 increased from 23 to $30 \%$. In parallel, the $16: 3$ content decreased dramatically from 10 to $2 \%$, and $20: 5$ decreased from 25 to $15 \%$ (Tables 2 and 6). Similar changes were observed in the main lipid classes (TAG, DGD, and MDG) where the effect was especially clear for $16: 3$ which diminished to a third at $1 /$ 5 nitrogen concentration with respect to the experiments carried out using the standard medium (Table 6).

At $D_{3}$ (maximum biomass productivity point) similar changes were observed when the nitrogen concen-

Table 6

Lipid and fatty acid composition of P. tricornutum cultured at dilution rate $2\left(D=0.012 \mathrm{~h}^{-1}\right)$ and one-fifth nitrogen concentration $(2 \mathrm{mmol})^{\mathrm{a}}$

\begin{tabular}{|c|c|c|c|c|c|c|c|c|c|c|c|c|c|}
\hline & \multicolumn{13}{|c|}{ Lipid $^{\mathrm{b}}(\%$ of fatty acids) } \\
\hline & MAG & DAG & TAG & SQD & DGD & MGD & PI & $\mathrm{PC}$ & PG & $\mathrm{PE}$ & PLX1 & PLX2 & Biomass \\
\hline $14: 0$ & $\begin{array}{l}5.3 \\
(0.5)\end{array}$ & $\begin{array}{l}8.5 \\
(0.7)\end{array}$ & $\begin{array}{l}9.4 \\
(0.1)\end{array}$ & $\begin{array}{l}13.7 \\
(0.3)\end{array}$ & $\begin{array}{l}3.6 \\
(0.1)\end{array}$ & $\begin{array}{l}8.5 \\
(0.9)\end{array}$ & $\begin{array}{l}5.0 \\
(1.8)\end{array}$ & $\begin{array}{l}6.2 \\
(1.1)\end{array}$ & $\begin{array}{l}11.5 \\
(0.3)\end{array}$ & $\begin{array}{l}4.8 \\
(4.8)\end{array}$ & $\begin{array}{l}7.9 \\
(0.6)\end{array}$ & $\begin{array}{l}7.9 \\
(1.0)\end{array}$ & $\begin{array}{l}8.7 \\
(0.1)\end{array}$ \\
\hline $16: 0$ & $\begin{array}{l}21.7 \\
(0.5)\end{array}$ & $\begin{array}{l}19.7 \\
(0.6)\end{array}$ & $\begin{array}{l}24.3 \\
(0.6)\end{array}$ & $\begin{array}{l}36.1 \\
(0.4)\end{array}$ & $\begin{array}{l}21.2 \\
(0.1)\end{array}$ & $\begin{array}{l}16.9 \\
(0.5)\end{array}$ & $\begin{array}{l}34.8 \\
(3.1)\end{array}$ & $\begin{array}{l}13.8 \\
(2.0)\end{array}$ & $\begin{array}{l}15.6 \\
(4.0)\end{array}$ & $\begin{array}{l}25.5 \\
(2.1)\end{array}$ & $\begin{array}{l}22.2 \\
(2.0)\end{array}$ & $\begin{array}{l}14.3 \\
(1.7)\end{array}$ & $\begin{array}{l}27.3 \\
(0.6)\end{array}$ \\
\hline $16: 1$ & $\begin{array}{l}20.2 \\
(1.5)\end{array}$ & $\begin{array}{l}24.2 \\
(3.0)\end{array}$ & $\begin{array}{l}30.0 \\
(0.9)\end{array}$ & $\begin{array}{l}24.3 \\
(0.2)\end{array}$ & $\begin{array}{l}23.1 \\
(0.1)\end{array}$ & $\begin{array}{l}21.8 \\
(1.5)\end{array}$ & $\begin{array}{l}20.3 \\
(2.3)\end{array}$ & $\begin{array}{l}11.0 \\
(2.2)\end{array}$ & $\begin{array}{l}14.7 \\
(5.5)\end{array}$ & $\begin{array}{l}17.4 \\
(3.1)\end{array}$ & $\begin{array}{l}20.4 \\
(6.4)\end{array}$ & $\begin{array}{l}11.3 \\
(0.7)\end{array}$ & $\begin{array}{l}30.1 \\
(0.5)\end{array}$ \\
\hline $16: 2 n-4$ & $\begin{array}{l}6.7 \\
(6.7)\end{array}$ & $\begin{array}{l}4.7 \\
(3.3)\end{array}$ & $\begin{array}{l}1.9 \\
(0.9)\end{array}$ & $\begin{array}{l}0.9 \\
(0.0)\end{array}$ & $\begin{array}{l}3.9 \\
(0.1)\end{array}$ & $\begin{array}{l}3.2 \\
(0.4)\end{array}$ & $\begin{array}{l}1.6 \\
(0.6)\end{array}$ & $\begin{array}{l}0.6 \\
(0.2)\end{array}$ & $\begin{array}{l}0.3 \\
(0.3)\end{array}$ & $\begin{array}{l}9.2 \\
(9.2)\end{array}$ & $\begin{array}{l}3.6 \\
(3.6)\end{array}$ & $\begin{array}{l}1.9 \\
(0.9)\end{array}$ & $\begin{array}{l}1.1 \\
(0.0)\end{array}$ \\
\hline $16: 3 n-4$ & $\begin{array}{l}4.8 \\
(0.1)\end{array}$ & $\begin{array}{l}3.7 \\
(0.4)\end{array}$ & $\begin{array}{l}1.9 \\
(0.1)\end{array}$ & $\begin{array}{l}1.0 \\
(0.3)\end{array}$ & $\begin{array}{l}23.0 \\
(0.4)\end{array}$ & $\begin{array}{l}6.3 \\
(0.6)\end{array}$ & $\begin{array}{l}1.2 \\
(1.2)\end{array}$ & $\begin{array}{l}0.7 \\
(0.3)\end{array}$ & $\begin{array}{l}3.2 \\
(0.2)\end{array}$ & $\begin{array}{l}13.1 \\
(13.1)\end{array}$ & $\begin{array}{l}5.6 \\
(5.6)\end{array}$ & $\begin{array}{l}0.6 \\
(0.6)\end{array}$ & $\begin{array}{l}2.3 \\
(0.2)\end{array}$ \\
\hline $16: 4 n-1$ & $\begin{array}{l}0.0 \\
(0.0)\end{array}$ & $\begin{array}{l}0.0 \\
(0.0)\end{array}$ & $\begin{array}{l}0.1 \\
(0.0)\end{array}$ & $\begin{array}{l}0.0 \\
(0.0)\end{array}$ & $\begin{array}{l}0.7 \\
(0.0)\end{array}$ & $\begin{array}{l}0.0 \\
(0.0)\end{array}$ & $\begin{array}{l}0.0 \\
(0.0)\end{array}$ & $\begin{array}{l}0.0 \\
(0.0)\end{array}$ & $\begin{array}{l}0.0 \\
(0.0)\end{array}$ & $\begin{array}{l}0.0 \\
(0.0)\end{array}$ & $\begin{array}{l}0.0 \\
(0.0)\end{array}$ & $\begin{array}{l}0.0 \\
(0.0)\end{array}$ & $\begin{array}{l}0.1 \\
(0.1)\end{array}$ \\
\hline $18: 1 \mathrm{n}-9$ & $\begin{array}{l}2.4 \\
(0.0)\end{array}$ & $\begin{array}{l}2.6 \\
(0.2)\end{array}$ & $\begin{array}{l}3.3 \\
(0.3)\end{array}$ & $\begin{array}{l}1.8 \\
(0.1)\end{array}$ & $\begin{array}{l}1.5 \\
(0.1)\end{array}$ & $\begin{array}{l}3.3 \\
(0.3)\end{array}$ & $\begin{array}{l}4.8 \\
(0.0)\end{array}$ & $\begin{array}{l}6.7 \\
(0.8)\end{array}$ & $\begin{array}{l}6.9 \\
(1.7)\end{array}$ & $\begin{array}{l}0.0 \\
(0.0)\end{array}$ & $\begin{array}{l}2.2 \\
(2.2)\end{array}$ & $\begin{array}{l}8.7 \\
(0.8)\end{array}$ & $\begin{array}{l}3.6 \\
(0.1)\end{array}$ \\
\hline $18: \ln -7$ & $\begin{array}{l}0.0 \\
(0.0)\end{array}$ & $\begin{array}{l}0.5 \\
(0.1)\end{array}$ & $\begin{array}{l}0.3 \\
(0.1)\end{array}$ & $\begin{array}{l}0.9 \\
(0.0)\end{array}$ & $\begin{array}{l}0.5 \\
(0.2)\end{array}$ & $\begin{array}{l}0.7 \\
(0.2)\end{array}$ & $\begin{array}{l}0.5 \\
(0.5)\end{array}$ & $\begin{array}{l}0.9 \\
(0.0)\end{array}$ & $\begin{array}{l}2.2 \\
(0.6)\end{array}$ & $\begin{array}{l}0.0 \\
(0.0)\end{array}$ & $\begin{array}{l}0.0 \\
(0.0)\end{array}$ & $\begin{array}{l}0.4 \\
(0.4)\end{array}$ & $\begin{array}{l}0.6 \\
(0.0)\end{array}$ \\
\hline $18: 2 n-6$ & $\begin{array}{l}2.1 \\
(0.1)\end{array}$ & $\begin{array}{l}1.1 \\
(0.2)\end{array}$ & $\begin{array}{l}1.0 \\
(0.0)\end{array}$ & $\begin{array}{l}1.1 \\
(0.0)\end{array}$ & $\begin{array}{l}1.1 \\
(0.0)\end{array}$ & $\begin{array}{l}3.6 \\
(0.6)\end{array}$ & $\begin{array}{l}5.7 \\
(0.3)\end{array}$ & $\begin{array}{l}10.7 \\
(1.2)\end{array}$ & $\begin{array}{l}7.4 \\
(2.6)\end{array}$ & $\begin{array}{l}0.0 \\
(0.0)\end{array}$ & $\begin{array}{l}3.5 \\
(3.5)\end{array}$ & $\begin{array}{l}7.9 \\
(1.1)\end{array}$ & $\begin{array}{l}1.5 \\
(0.1)\end{array}$ \\
\hline $20: 4 n-6$ & $\begin{array}{l}0.0 \\
(0.0)\end{array}$ & $\begin{array}{l}0.0 \\
(0.0)\end{array}$ & $\begin{array}{l}0.1 \\
(0.0)\end{array}$ & $\begin{array}{l}0.0 \\
(0.0)\end{array}$ & $\begin{array}{l}0.0 \\
(0.0)\end{array}$ & $\begin{array}{l}0.3 \\
(0.0)\end{array}$ & $\begin{array}{l}0.0 \\
(0.0)\end{array}$ & $\begin{array}{l}1.0 \\
(0.1)\end{array}$ & $\begin{array}{l}0.0 \\
(0.0)\end{array}$ & $\begin{array}{l}0.0 \\
(0.0)\end{array}$ & $\begin{array}{l}0.0 \\
(0.0)\end{array}$ & $\begin{array}{l}0.0 \\
(0.0)\end{array}$ & $\begin{array}{l}0.1 \\
(0.0)\end{array}$ \\
\hline $20: 5 n-3$ & $\begin{array}{l}11.9 \\
(1.3)\end{array}$ & $\begin{array}{l}13.8 \\
(3.1)\end{array}$ & $\begin{array}{l}18.5 \\
(0.0)\end{array}$ & $\begin{array}{l}8.1 \\
(0.0)\end{array}$ & $\begin{array}{l}8.9 \\
(0.1)\end{array}$ & $\begin{array}{l}20.7 \\
(3.9)\end{array}$ & $\begin{array}{l}11.4 \\
(0.6)\end{array}$ & $\begin{array}{l}23.6 \\
(1.6)\end{array}$ & $\begin{array}{l}22.9 \\
(3.3)\end{array}$ & $\begin{array}{l}17.7 \\
(0.8)\end{array}$ & $\begin{array}{l}19.6 \\
(1.6)\end{array}$ & $\begin{array}{l}20.9 \\
(0.6)\end{array}$ & $\begin{array}{l}14.7 \\
(0.7)\end{array}$ \\
\hline $22: 6 n-3$ & $\begin{array}{l}2.6 \\
(0.3)\end{array}$ & $\begin{array}{l}0.8 \\
(0.2)\end{array}$ & $\begin{array}{l}0.4 \\
(0.0)\end{array}$ & $\begin{array}{l}0.3 \\
(0.3)\end{array}$ & $\begin{array}{l}0.6 \\
(0.2)\end{array}$ & $\begin{array}{l}0.9 \\
(0.9)\end{array}$ & $\begin{array}{l}1.3 \\
(1.3)\end{array}$ & $\begin{array}{l}8.3 \\
(0.6)\end{array}$ & $\begin{array}{l}5.6 \\
(0.3)\end{array}$ & $\begin{array}{l}0.0 \\
(0.0)\end{array}$ & $\begin{array}{l}5.6 \\
(5.6)\end{array}$ & $\begin{array}{l}6.1 \\
(1.7)\end{array}$ & $\begin{array}{l}1.0 \\
(0.1)\end{array}$ \\
\hline $\mathrm{USCFAs}^{\mathrm{c}}$ & $\begin{array}{l}5.2 \\
(0.7)\end{array}$ & $\begin{array}{l}13.4 \\
(5.0)\end{array}$ & $\begin{array}{l}2.6 \\
(1.0)\end{array}$ & $\begin{array}{l}0.2 \\
(0.2)\end{array}$ & $\begin{array}{l}0.0 \\
(0.0)\end{array}$ & $\begin{array}{l}3.6 \\
(2.8)\end{array}$ & $\begin{array}{l}0.0 \\
(0.0)\end{array}$ & $\begin{array}{l}0.0 \\
(0.0)\end{array}$ & $\begin{array}{l}0.0 \\
(0.0)\end{array}$ & $\begin{array}{l}0.0 \\
(0.0)\end{array}$ & $\begin{array}{l}0.0 \\
(0.0)\end{array}$ & $\begin{array}{l}0.4 \\
(0.4)\end{array}$ & $\begin{array}{l}1.3 \\
(0.2)\end{array}$ \\
\hline Others & 17.2 & 7.0 & 6.3 & 11.5 & 11.9 & 10.2 & 13.4 & 16.5 & 9.8 & 12.4 & 9.5 & 19.7 & 7.7 \\
\hline
\end{tabular}

${ }^{a}$ Values are averages of three independent measurements. Standard errors are shown in parentheses.

${ }^{\mathrm{b}}$ MAG, DAG and TAG stated for mono-, di-, and triacylglycerols, respectively; SQD, DGD, and MGD stated for sulfoquinovosyl-, digalactosyl-, and monogalactosyldiacylglycerols, respectively; PI, PC, PG, and PE stated for phosphatidylinositol, -choline, -glycerol, and -ethanolamine, respectively; PLX are unknown phospholipids.

${ }^{\mathrm{c}}$ USCFAs = unknown short-chain fatty acids. For additional details see López Alonso et al. (1998). 
Table 7

Lipid and fatty acid composition of $P$. tricornutum cultured at dilution rate $3\left(D=0.024 \mathrm{~h}^{-1}\right)$ and half nitrogen concentration $(5 \mathrm{mmol})^{\mathrm{a}}$

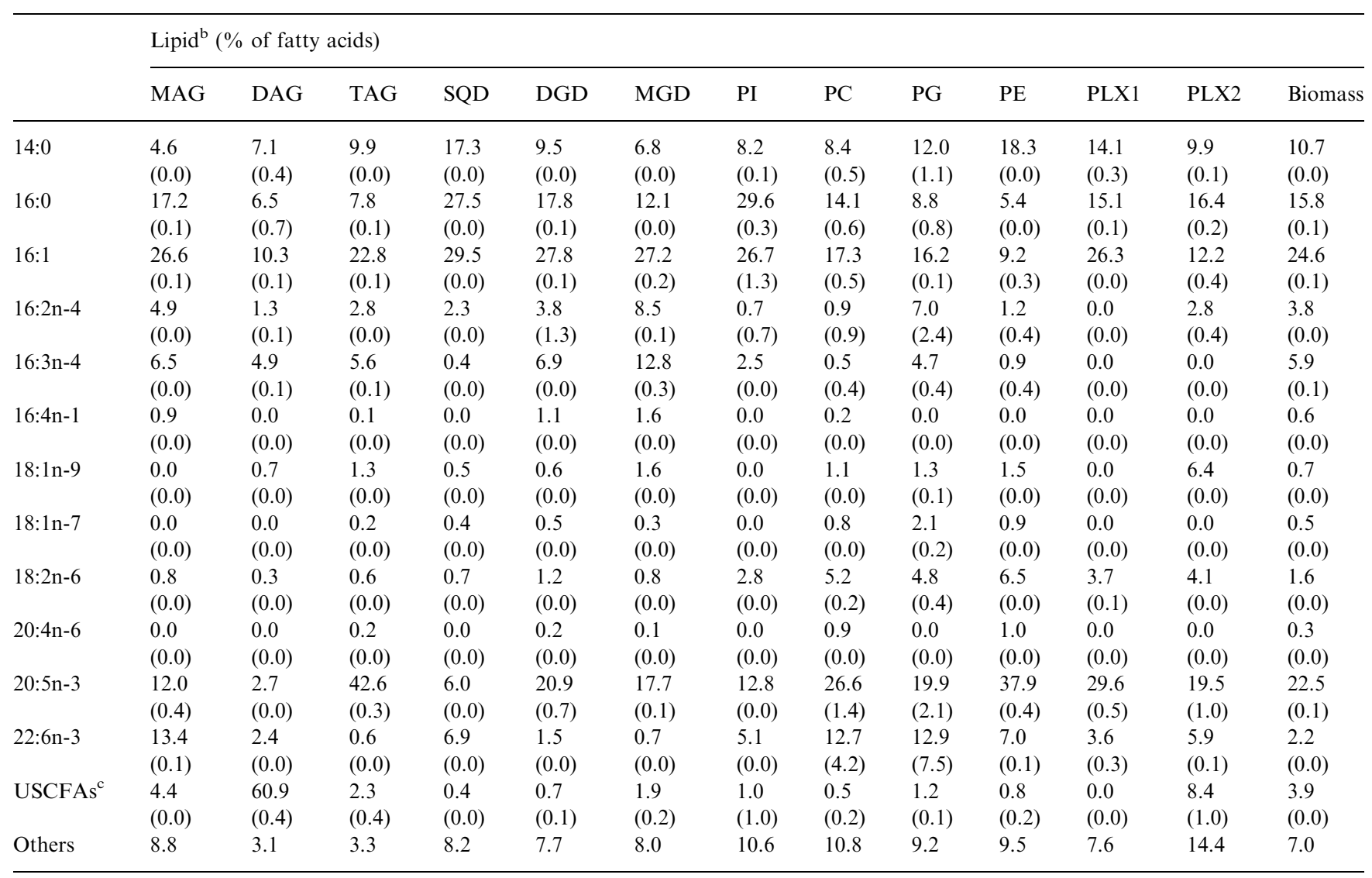

${ }^{a}$ Values are averages of three independent measurements. Standard errors are shown in parentheses.

${ }^{\mathrm{b}}$ MAG, DAG and TAG stated for mono-, di-, and triacylglycerols, respectively; SQD, DGD, and MGD stated for sulfoquinovosyl-, digalactosyl-, and monogalactosyldiacylglycerols, respectively; PI, PC, PG, and PE stated for phosphatidylinositol, -choline, -glycerol, and -ethanolamine, respectively; PLX are unknown phospholipids.

${ }^{\mathrm{c}}$ USCFAs = unknown short-chain fatty acids. For additional details see López Alonso et al. (1998).

tration was decreased. The fatty acids found in the biomass showed a notable increase in 16:0 and 16:1 with decrease of 16:2, 16:3 and 20:5 when nitrogen concentration decreased (compare Tables 3 and 8). For example, 16:0 increased from 11 to $20 \%$ of total fatty acids. These changes were even more extensively reflected in some GLs. For example, the decrease was especially large for $16: 3$, a fatty acid mainly located in GLs (López Alonso et al., 1998): 16:3 was reduced from 29 to 3\% in DGD as the nitrogen concentration was changed from normal to one-fifth the normal value (Tables 3 and 8).

Similar responses to $\mathrm{N}$-deprivation have been reported by others (Pohl and Zurheide, 1979; Piorreck and Pohl, 1984, Piorreck et al., 1984). Similar behaviour has been observed also when nutrients other than $\mathrm{N}$ become limiting (Reitan et al., 1994) although no detailed analysis of lipid classes has been reported in this case. Apparently nitrogen deprivation triggers a response that leads to a reduction of biomass gener- ation while the metabolism is redirected to the synthesis of reserve components, namely saturated fatty acids, thus preparing the cells for a starvation period.

\subsubsection{Lipid class composition}

The most important changes caused by the decrease in nitrogen supply were observed at dilution rate $D_{2}$ and were mainly in the GL classes (Fig. 2). GL fraction decreased from 21 to $12 \%$ and both of the main GL classes, MGD and DGD, exhibited a similar trend. DGD, for example, decreased from 12 to $5 \%$ (Fig. 2). Conversely, NLs and PLs increased in parallel from about 73 to $79 \%$ and from 6 to $8 \%$, respectively (Fig. 2). TAG was the lipid class with the highest increase, from 69 to $75 \%$ (Fig. 2).

It is well documented that most microalgae increase their total lipid content in response to $\mathrm{N}$-deprivation (Shifrin and Chisholm, 1980; Piorreck and Pohl, 1984; Álvarez Cobelas, 1989; Ahlgren et al., 1992). Although there are only a few studies on detailed changes in 
Table 8

Lipid and fatty acid composition of $P$. tricornutum cultured at dilution rate $3\left(D=0.024 \mathrm{~h}^{-1}\right)$ and one-fifth nitrogen concentration $(2 \text { mmol })^{\text {a }}$

\begin{tabular}{|c|c|c|c|c|c|c|c|c|c|c|c|c|c|}
\hline & \multicolumn{13}{|c|}{ Lipid $^{\mathrm{b}}(\%$ of fatty acids) } \\
\hline & MAG & DAG & TAG & SQD & DGD & MGD & PI & PC & PG & $\mathrm{PE}$ & PLX1 & PLX2 & Biomass \\
\hline $14: 0$ & $\begin{array}{l}22.2 \\
(6.7)\end{array}$ & $\begin{array}{l}13.7 \\
(0.3)\end{array}$ & $\begin{array}{l}10.2 \\
(0.3)\end{array}$ & $\begin{array}{l}15.2 \\
(0.0)\end{array}$ & $\begin{array}{l}11.8 \\
(0.0)\end{array}$ & $\begin{array}{l}4.9 \\
(0.0)\end{array}$ & $\begin{array}{l}5.8 \\
(0.1)\end{array}$ & $\begin{array}{l}6.8 \\
(0.6)\end{array}$ & $\begin{array}{l}9.4 \\
(2.5)\end{array}$ & $\begin{array}{l}20.1 \\
(0.1)\end{array}$ & $\begin{array}{l}11.8 \\
(0.3)\end{array}$ & $\begin{array}{l}7.1 \\
(0.0)\end{array}$ & $\begin{array}{l}11.3 \\
(0.0)\end{array}$ \\
\hline $16: 0$ & $\begin{array}{l}13.4 \\
(2.0)\end{array}$ & $\begin{array}{l}14.3 \\
(1.0)\end{array}$ & $\begin{array}{l}9.1 \\
(0.1)\end{array}$ & $\begin{array}{l}34.7 \\
(0.0)\end{array}$ & $\begin{array}{l}19.1 \\
(0.0)\end{array}$ & $\begin{array}{l}10.9 \\
(0.0)\end{array}$ & $\begin{array}{l}30.9 \\
(1.4)\end{array}$ & $\begin{array}{l}15.5 \\
(1.7)\end{array}$ & $\begin{array}{l}9.3 \\
(2.3)\end{array}$ & $\begin{array}{l}8.5 \\
(0.0)\end{array}$ & $\begin{array}{l}21.2 \\
(0.5)\end{array}$ & $\begin{array}{l}16.1 \\
(0.1)\end{array}$ & $\begin{array}{l}19.5 \\
(0.0)\end{array}$ \\
\hline $16: 1$ & $\begin{array}{l}22.6 \\
(3.3)\end{array}$ & $\begin{array}{l}24.3 \\
(1.1)\end{array}$ & $\begin{array}{l}20.6 \\
(0.4)\end{array}$ & $\begin{array}{l}35.4 \\
(0.0)\end{array}$ & $\begin{array}{l}26.2 \\
(0.1)\end{array}$ & $\begin{array}{l}19.3 \\
(0.0)\end{array}$ & $\begin{array}{l}26.0 \\
(0.5)\end{array}$ & $\begin{array}{l}13.6 \\
(1.5)\end{array}$ & $\begin{array}{l}14.9 \\
(2.6)\end{array}$ & $\begin{array}{l}8.5 \\
(0.0)\end{array}$ & $\begin{array}{l}33.7 \\
(0.7)\end{array}$ & $\begin{array}{l}7.4 \\
(1.7)\end{array}$ & $\begin{array}{l}28.1 \\
(0.3)\end{array}$ \\
\hline $16: 2 n-4$ & $\begin{array}{l}2.0 \\
(0.2)\end{array}$ & $\begin{array}{l}1.9 \\
(0.1)\end{array}$ & $\begin{array}{l}1.8 \\
(0.1)\end{array}$ & $\begin{array}{l}3.2 \\
(0.0)\end{array}$ & $\begin{array}{l}6.1 \\
(2.0)\end{array}$ & $\begin{array}{l}6.8 \\
(0.1)\end{array}$ & $\begin{array}{l}1.9 \\
(1.2)\end{array}$ & $\begin{array}{l}1.2 \\
(0.2)\end{array}$ & $\begin{array}{l}2.4 \\
(2.4)\end{array}$ & $\begin{array}{l}1.1 \\
(0.0)\end{array}$ & $\begin{array}{l}1.2 \\
(0.1)\end{array}$ & $\begin{array}{l}1.9 \\
(0.7)\end{array}$ & $\begin{array}{l}2.9 \\
(0.3)\end{array}$ \\
\hline $16: 3 n-4$ & $\begin{array}{l}3.0 \\
(0.9)\end{array}$ & $\begin{array}{l}3.7 \\
(0.3)\end{array}$ & $\begin{array}{l}2.9 \\
(0.6)\end{array}$ & $\begin{array}{l}0.0 \\
(0.0)\end{array}$ & $\begin{array}{l}2.8 \\
(1.9)\end{array}$ & $\begin{array}{l}11.3 \\
(0.0)\end{array}$ & $\begin{array}{l}0.0 \\
(0.0)\end{array}$ & $\begin{array}{l}0.4 \\
(0.1)\end{array}$ & $\begin{array}{l}0.0 \\
(0.0)\end{array}$ & $\begin{array}{l}0.0 \\
(0.0)\end{array}$ & $\begin{array}{l}0.7 \\
(0.0)\end{array}$ & $\begin{array}{l}0.6 \\
(0.6)\end{array}$ & $\begin{array}{l}2.9 \\
(0.0)\end{array}$ \\
\hline $16: 4 n-1$ & $\begin{array}{l}0.0 \\
(0.0)\end{array}$ & $\begin{array}{l}0.1 \\
(0.1)\end{array}$ & $\begin{array}{l}0.0 \\
(0.0)\end{array}$ & $\begin{array}{l}0.0 \\
(0.0)\end{array}$ & $\begin{array}{l}1.1 \\
(0.0)\end{array}$ & $\begin{array}{l}2.3 \\
(0.0)\end{array}$ & $\begin{array}{l}0.0 \\
(0.0)\end{array}$ & $\begin{array}{l}0.0 \\
(0.0)\end{array}$ & $\begin{array}{l}0.0 \\
(0.0)\end{array}$ & $\begin{array}{l}0.0 \\
(0.0)\end{array}$ & $\begin{array}{l}0.0 \\
(0.0)\end{array}$ & $\begin{array}{l}0.0 \\
(0.0)\end{array}$ & $\begin{array}{l}0.5 \\
(0.0)\end{array}$ \\
\hline $18: 1 \mathrm{n}-7$ & $\begin{array}{l}0.0 \\
(0.0)\end{array}$ & $\begin{array}{l}0.0 \\
(0.0)\end{array}$ & $\begin{array}{l}0.1 \\
(0.0)\end{array}$ & $\begin{array}{l}0.0 \\
(0.0)\end{array}$ & $\begin{array}{l}0.4 \\
(0.0)\end{array}$ & $\begin{array}{l}0.3 \\
(0.0)\end{array}$ & $\begin{array}{l}0.0 \\
(0.0)\end{array}$ & $\begin{array}{l}0.4 \\
(0.0)\end{array}$ & $\begin{array}{l}0.0 \\
(0.0)\end{array}$ & $\begin{array}{l}0.6 \\
(0.0)\end{array}$ & $\begin{array}{l}0.0 \\
(0.0)\end{array}$ & $\begin{array}{l}0.0 \\
(0.0)\end{array}$ & $\begin{array}{l}0.4 \\
(0.0)\end{array}$ \\
\hline $18: 2 n-6$ & $\begin{array}{l}0.9 \\
(0.1)\end{array}$ & $\begin{array}{l}0.5 \\
(0.0)\end{array}$ & $\begin{array}{l}0.6 \\
(0.0)\end{array}$ & $\begin{array}{l}0.8 \\
(0.0)\end{array}$ & $\begin{array}{l}1.2 \\
(0.0)\end{array}$ & $\begin{array}{l}0.8 \\
(0.0)\end{array}$ & $\begin{array}{l}3.7 \\
(0.3)\end{array}$ & $\begin{array}{l}4.5 \\
(0.5)\end{array}$ & $\begin{array}{l}2.6 \\
(0.7)\end{array}$ & $\begin{array}{l}5.4 \\
(0.0)\end{array}$ & $\begin{array}{l}2.2 \\
(0.3)\end{array}$ & $\begin{array}{l}1.6 \\
(0.0)\end{array}$ & $\begin{array}{l}1.5 \\
(0.0)\end{array}$ \\
\hline $20: 4 n-6$ & $\begin{array}{l}0.0 \\
(0.0)\end{array}$ & $\begin{array}{l}0.0 \\
(0.0)\end{array}$ & $\begin{array}{l}0.3 \\
(0.0)\end{array}$ & $\begin{array}{l}0.0 \\
(0.0)\end{array}$ & $\begin{array}{l}0.4 \\
(0.0)\end{array}$ & $\begin{array}{l}0.0 \\
(0.0)\end{array}$ & $\begin{array}{l}0.0 \\
(0.0)\end{array}$ & $\begin{array}{l}0.4 \\
(0.0)\end{array}$ & $\begin{array}{l}0.0 \\
(0.0)\end{array}$ & $\begin{array}{l}0.6 \\
(0.0)\end{array}$ & $\begin{array}{l}0.0 \\
(0.0)\end{array}$ & $\begin{array}{l}0.0 \\
(0.0)\end{array}$ & $\begin{array}{l}0.1 \\
(0.0)\end{array}$ \\
\hline $20: 5 n-3$ & $\begin{array}{l}7.5 \\
(0.4)\end{array}$ & $\begin{array}{l}3.3 \\
(0.1)\end{array}$ & $\begin{array}{l}48.0 \\
(2.0)\end{array}$ & $\begin{array}{l}4.3 \\
(0.3)\end{array}$ & $\begin{array}{l}19.6 \\
(0.0)\end{array}$ & $\begin{array}{l}22.0 \\
(0.1)\end{array}$ & $\begin{array}{l}13.2 \\
(1.0)\end{array}$ & $\begin{array}{l}27.2 \\
(3.0)\end{array}$ & $\begin{array}{l}34.8 \\
(8.8)\end{array}$ & $\begin{array}{l}38.0 \\
(0.2)\end{array}$ & $\begin{array}{l}13.0 \\
(1.0)\end{array}$ & $\begin{array}{l}8.0 \\
(0.1)\end{array}$ & $\begin{array}{l}20.0 \\
(0.1)\end{array}$ \\
\hline $22: 6 n-3$ & $\begin{array}{l}6.9 \\
(4.9)\end{array}$ & $\begin{array}{l}1.7 \\
(1.1)\end{array}$ & $\begin{array}{l}0.2 \\
(0.0)\end{array}$ & $\begin{array}{l}0.5 \\
(0.0)\end{array}$ & $\begin{array}{l}2.0 \\
(0.0)\end{array}$ & $\begin{array}{l}0.8 \\
(0.0)\end{array}$ & $\begin{array}{l}5.0 \\
(0.2)\end{array}$ & $\begin{array}{l}15.3 \\
(6.1)\end{array}$ & $\begin{array}{l}19.7 \\
(3.4)\end{array}$ & $\begin{array}{l}6.2 \\
(0.0)\end{array}$ & $\begin{array}{l}2.2 \\
(0.0)\end{array}$ & $\begin{array}{l}1.6 \\
(1.0)\end{array}$ & $\begin{array}{l}1.9 \\
(0.0)\end{array}$ \\
\hline $\mathrm{USCFAs}^{\mathrm{c}}$ & $\begin{array}{l}5.7 \\
(1.5)\end{array}$ & $\begin{array}{l}29.2 \\
(2.5)\end{array}$ & $\begin{array}{l}2.2 \\
(0.1)\end{array}$ & $\begin{array}{l}0.0 \\
(0.0)\end{array}$ & $\begin{array}{l}0.6 \\
(0.0)\end{array}$ & $\begin{array}{l}2.5 \\
(0.1)\end{array}$ & $\begin{array}{l}0.2 \\
(0.2)\end{array}$ & $\begin{array}{l}0.3 \\
(0.0)\end{array}$ & $\begin{array}{l}0.0 \\
(0.0)\end{array}$ & $\begin{array}{l}0.5 \\
(0.5)\end{array}$ & $\begin{array}{l}2.0 \\
(0.0)\end{array}$ & $\begin{array}{l}5.5 \\
(0.1)\end{array}$ & $\begin{array}{l}2.2 \\
(0.0)\end{array}$ \\
\hline Others & 14.2 & 6.2 & 3.1 & 5.6 & 8.2 & 16.2 & 12.6 & 13.6 & 6.8 & 9.6 & 9.2 & 43.4 & 7.6 \\
\hline
\end{tabular}

${ }^{\text {a }}$ Values are averages of three independent measurements. Standard errors are shown in parentheses.

${ }^{\mathrm{b}}$ MAG, DAG and TAG stated for mono-, di-, and triacylglycerols, respectively; SQD, DGD, and MGD stated for sulfoquinovosyl-, digalactosyl-, and monogalactosyldiacylglycerols, respectively; PI, PC, PG, and PE stated for phosphatidylinositol, -choline, -glycerol, and -ethanolamine, respectively; PLX are unknown phospholipids.

${ }^{\mathrm{c}}$ USCFAs = unknown short-chain fatty acids. For additional details see López Alonso et al. (1998).

lipid classes, the depletion of polar lipids and the increase of NL seem to be a general response to Nstress in microalgae (Pohl and Zurheide, 1979; Regnault et al., 1995). Similar trends have been reported for $P$. tricornutum in batch cultures (Parrish and Wangersky, 1987) although deficiencies in the analytical procedures followed in that work precluded a deeper discussion. At dilution rate $D_{3}$ the picture was dramatically changed and a decrease in the nitrogen concentration in the fresh medium caused the NLs to diminish from 50 to $28 \%$ while GLs increased from 39 to $51 \%$ (Fig. 3). The other polar lipid fraction, PLs, was also significantly increased from 11 to $21 \%$. Therefore, surprisingly, the polar lipids increased from 50 to $72 \%$ when nitrogen concentration decreased from the standard value to $1 / 5$ (Fig. 3). This effect was especially marked in DGD which increased from 15 to $36 \%$ while the other GLs, MGD and SQD, slightly decreased when $\mathrm{N}$-content was reduced (Fig. 3). This behaviour at dilution rate $D_{3}$ conflicts with the usual one reported in the references cited above and with our own results for $D_{2}$.

If observations are made at the level of dry weight content we can consider the exact nature of changes. At $D_{2}$, acyl lipids increased from 11 to $19 \%$ of biomass dry weight when nitrogen concentration decreased. Conversely, at $D_{3}$, the acyl lipid content was nearly undisturbed (ca. $11 \%$ of dry weight) by the changes in nitrogen concentration (data not shown). Therefore, at $D_{2}$, the GL changes described in percentage of total lipids were mostly 'apparent', in fact GLs slightly increased from 2.0 to $2.2 \%$ of dry weight. when nitrogen concentration decreased (data not shown). However, at the same time, NLs increased from 8.4 to $14.6 \%$ of day weight (data not shown) representing a relative decrease of GLs. Conversely, at $D_{3}$, both changes, i.e. decrease in NLs and increase in GLs were 'real' in terms of dry weight A biological ex- 
planation for this phenomenon is lacking. Apparently young cells seem to respond to N-limitation by improving the system (membranes) of $\mathrm{N}$-fixation.

These observations illustrate that average cell age (dilution rate) and nitrogen availability interact. Hence, the common assertion that N-starvation increases lipid content in microalgae (Pohl and Zurheide, 1979; Shifrin and Chisholm, 1980; Piorreck and Pohl, 1984; Piorreck et al., 1984; Álvarez Cobelas, 1989 ) is not always true; the effect of N-availability depends also on cell age as shown here. N-starvation may increase or may leave unchanged the total lipid content depending on the dilution rate. This supports the suggestion that ageing effects and nutrient limitation effects cannot be discriminated, or may be confused (Álvarez Cobelas, 1989) in batch cultures. Moreover, the effect may be quite different on the different lipid classes depending on dilution rate. What seems to be well supported is that N-starvation always decreases the amount of polyunsaturated fatty acids.

Summarising, fatty acid composition of P. tricornutum biomass was relatively more stable than lipid class composition; in other words, $P$. tricornutum reacts to changes in culture conditions mostly by retailoring its lipid classes and to a lesser extent, altering its fatty acid composition. The direction of the changes in lipid composition, elicited by environmental changes, cannot be clearly predicted because culture factors interact in an unpredictable way. Also, as we have shown, the response of a microalgal culture to a factor (cell age or nitrogen concentration) is affected by the type of culture (batch or continuous).

\section{Acknowledgements}

This work was supported by EU project BE97-4015, contract BRPR97-0537, and by the Plan Andaluz de Investigación CVI0173. The authors want to thank Prof. Yusuf Chisti for his revision and edition of the manuscript. We would also like to thank the anonymous reviewers for their patience in correcting a lot of mistakes in the manuscript.

\section{References}

Ahlgren, G., Gustafsson, I.-B., Boberg, M., 1992. Faty acid content and chemical composition of freshwater microalgae. The Journal of Phycology 28, 37-50.

Álvarez Cobelas, M., 1989. Lipids in microalgae: a review. Part II: Environment. Grasas y Aceites 40, 213-223.

Bell, M.V., Pond, D., 1996. Lipid composition during growth of motile and coccolith forms of Emiliania huxleyi. Phytochemistry $42(2), 465-471$
Brown, M.R., Dunstan, G.A., Norwood, S.J., Miller, K.A., 1996. Effects of harvest stage and light on the biochemical composition of the diatom Thalassiosira pseudonana. The Journal of Phycology 32, 64-73.

Dunstan, G.A., Volkman, J.K., Barrett, S.M., Garland, C.D., 1993. Changes in the lipid composition and maximisation of the polyunsaturated fatty acid content of three microalgae grown in mass culture. The Journal of Applied Phycology 5, 71-83.

Gurr, M.I., Harwood, J.L., 1991. Lipid Biochemistry. Chapman \& Hall, London.

Hodgson, P.A., Henderson, R.J., Sargent, J.R., Leftley, J.W., 1991. Patterns of variation in the lipid class and fatty acid composition of Nannochloropsis oculata (Eustigmatophyceae) during batch culture. Part I: The growth cycle. The Journal of Applied Phycology $3,169-181$.

Lombardi, A.T., Wangersky, P.J., 1995. Particulate lipid class composition of three marine phytoplankters Chaetoceros gracilis, Isochrysis galbana (Tahiti) and Dunaliella tertiolecta grown in batch culture. Hydrobiologia 306, 1-6.

López Alonso, D., Belarbi, E.-H., Rodríguez-Ruiz, J., Segura, C.I., Giménez, A., 1998. Acyl lipids of three microalgae. Phytochemistry 47 (8), 1473-1481.

Molina Grima, E., Garcia, F., Sánchez, J.A., Sevilla, J.M.F., Acién, F.G., Contreras, A., 1994. A mathematical model of microalgal growth in light-limited chemostat culture. Journal of Chemical Technology and Biotechnology 61, 167-173.

Molina Grima, E., Sánchez, J.A., García, F., García, J.L., Acién, F.G., 1994. Outdoor culture of Isochrysis galbana ALII-4 in a closed tubular photobioreactor. Journal of Biotechnology 37, 159-166.

Molina Grima, E., Sánchez, J.A., García, F., García, J.L., López, Alonso, D., 1993. n-3 PUFA productivity in chemostat cultures of microalgae. Applied Microbiology and Biotechnology 38, 599605.

Parrish, C.C., Wangersky, P.J., 1987. Particulate and dissolved lipid classes in cultures of Phaeodactylum tricornutum grown in cage culture turbidostats with a range of nitrogen supply rates. Marine Ecology Progress Series 35, 119-128.

Piorreck, M., Pohl, P., 1984. Formation of biomass, total protein, chlorophylls, lipids and fatty acids in green and blue-green algae during one growth phase. Phytochemistry 23 (2), 217-223.

Piorreck, M., Baasch, K.-H., Pohl, P., 1984. Biomass production, total protein, chlorophylls, lipids and fatty acids of freshwater green and blue-green algae under different nitrogen regimes. Phytochemistry 23 (2), 207-216.

Pohl, P., Zurheide, F., 1979. Fatty acids and lipids of marine algae and the control of their biosynthesis by environmental factors. In: Marine Algae in Pharmaceutical Science. Walter de Gruyter, Berlin, pp. 473-523.

Regnault, A., Chervin, D., Chammai, A., Piton, F., Calvayrac, R., Mazliak, P., 1995. Lipid composition of Euglena gracilis in relation to carbon-nitrogen balance. Phytochemistry 40 (3), 725 733.

Reitan, K.I., Rainuzzo, J.R., Olsen, Y., 1994. Effect of nutrient limitation on fatty acid and lipid content of marine microalgae. The Journal of Phycology 30, 972-979.

Shifrin, N.S., Chisholm, S.W., 1980. Phytoplankton lipids: environmental influences on production and possible commercial applications. In: Algae Biomass. Elsevier/North-Holland Biomedical Press, Amsterdam, pp. 627-645.

Siron, R., Giusti, G., Berland, B., 1989. Changes in the fatty acid composition of Phaeodactylum tricornutum and Dunaliella tertiolecta during growth and under phosphorus deficiency. Marine Ecology Progress Series 55, 95-100. 